Prepared in cooperation with the Village of Chenequa, the Southeastern Wisconsin Regional Planning Commission and the Wisconsin Department of Natural Resources

\title{
Application of the Local Grid Refinement Package to an Inset Model Simulating the Interaction of Lakes, Wells, and Shallow Groundwater, Northwestern Waukesha County, Wisconsin
}

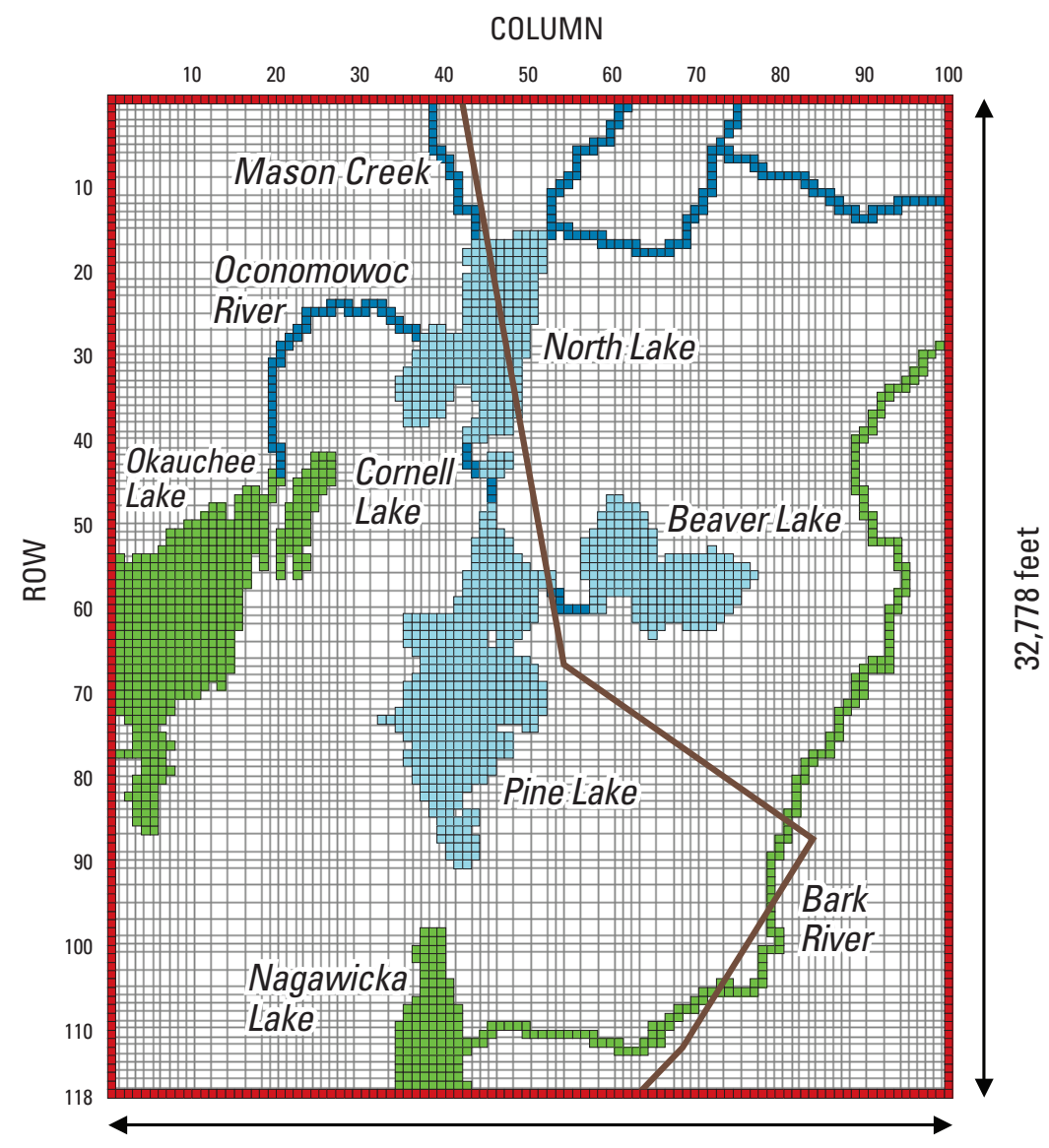

27,778 feet

\author{
EXPLANATION \\ Grid lines for child model \\ Constant-head conditions \\ E Streams and lakes from RIV package in MODFLOW \\ \#II Streams from SFR1 package in MODFLOW \\ 国 Lakes from LAK3 package in MODFLOW \\ Approximate location of Maquoketa Shale subcrop
}

Scientific Investigations Report 2010-5214 



\section{Application of the Local Grid Refinement Package to an Inset Model Simulating the Interaction of Lakes, Wells, and Shallow Groundwater, Northwestern Waukesha County, Wisconsin}

By D.T. Feinstein, C.P. Dunning, P.F. Juckem, and R.J. Hunt

Prepared in cooperation with the Village of Chenequa, the Southeastern Wisconsin Regional Planning Commission and the Wisconsin Department of Natural Resources

Scientific Investigations Report 2010-5214 


\title{
U.S. Department of the Interior \\ KEN SALAZAR, Secretary \\ U.S. Geological Survey \\ Marcia K. McNutt, Director
}

\author{
U.S. Geological Survey, Reston, Virginia: 2011
}

For more information on the USGS - the Federal source for science about the Earth, its natural and living resources, natural hazards, and the environment, visit http://www.usgs.gov or call 1-888-ASK-USGS

For an overview of USGS information products, including maps, imagery, and publications, visit http://www.usgs.gov/pubprod

To order this and other USGS information products, visit http://store.usgs.gov

Any use of trade, product, or firm names is for descriptive purposes only and does not imply endorsement by the U.S. Government.

Although this report is in the public domain, permission must be secured from the individual copyright owners to reproduce any copyrighted materials contained within this report.

Suggested citation:

Feinstein, D.T., Dunning, C.P., Juckem, P.F., and Hunt, R.J., 2010, Application of the Local Grid Refinement package to an inset model simulating the interactions of lakes, wells, and shallow groundwater, northwestern Waukesha County, Wisconsin: U.S. Geological Survey Scientific Investigations Report 2010-5214, 30 p. 


\section{Acknowledgments}

This report was funded by two Lake Management Planning Grants awarded by the Wisconsin Department of Natural Resources under the Chapter NR 190 Lake Management Planning Grant Program (LPL-1129-07 Modeling and LPL-1130-07 Water Budget—Village of Chenequa).

The project benefited greatly from the counsel and data provided by

Jeffrey Kante, Forester and Superintendent, Village of Chenequa;

Dr. Jeffrey Thornton, Principal Planner, Southeastern Wisconsin Regional Planning Commission;

Robert Nauta, RJN Environmental Services; and

John Jansen and Ted Powell, Rukert-Mielke Engineering.

Also key to the project were field investigations performed by William Rose, Hydrologist, USGS. Generous assistance with the LGR modeling package was provided by Steffen Mehl, Professor at California State University, Chico; and Christopher Hoard, Hydrogeologist, USGS.

The preparation of the report depended on timely contributions from USGS colleagues Michelle Greenwood, Reports Specialist; Leah Leonard, Science Support; Michael Eberle, Technical Publications Editor, and Rosemary Stenback, Illustrator. 



\section{Contents}

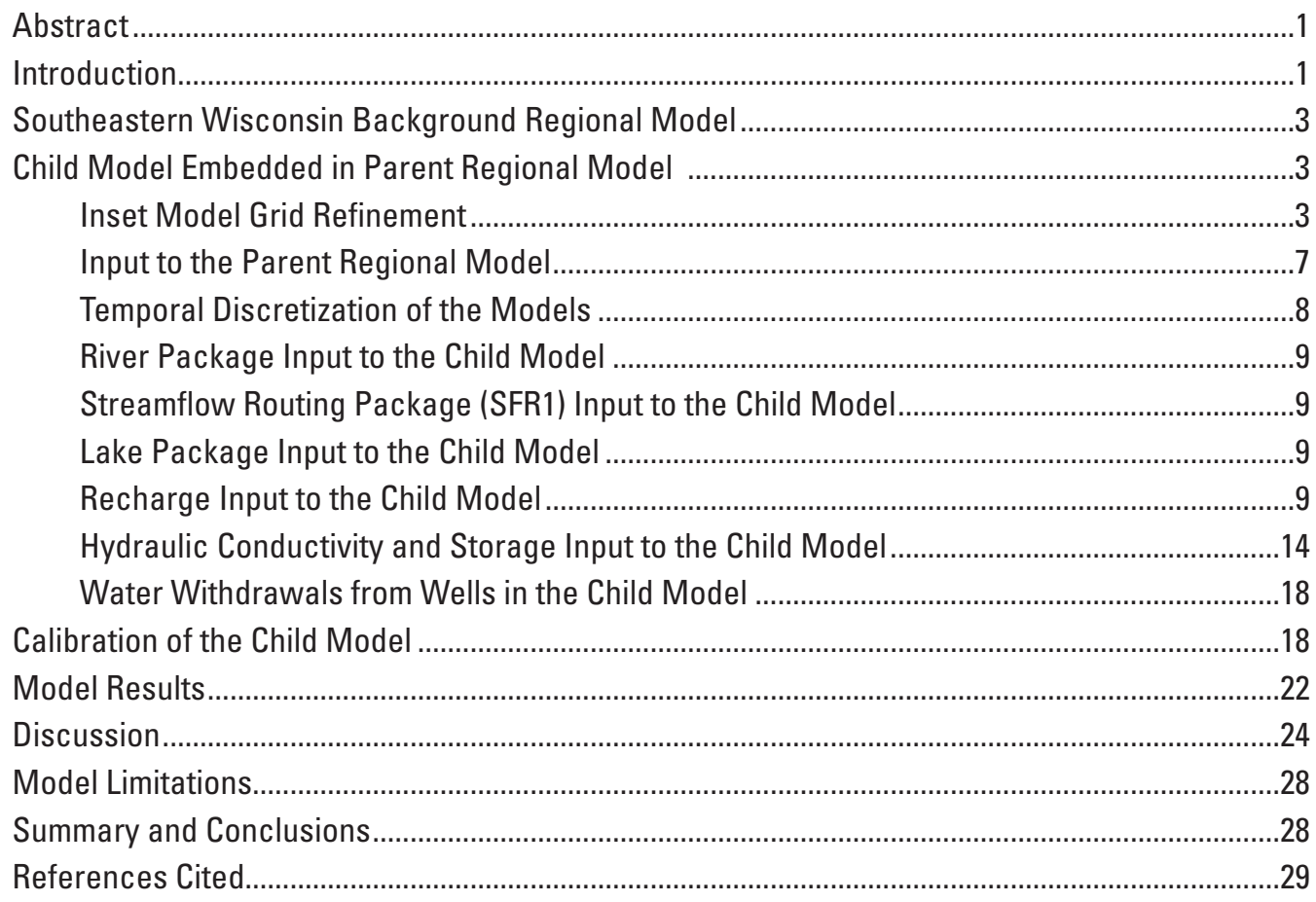

\section{Figures}

1. Map showing location of study area, near Chenequa, Waukesha County, Wisconsin

2. Stratigraphic section for southeastern Wisconsin ...........................................................

3. Model layering in example east-west section. $A$, Layering in background regional model. $B$, Layering in parent regional and child model..................................................5

4. Map showing location of the child model centered on Beaver, Pine, Cornell and North Lakes.............................................................................................................

5. Original discretization and boundary conditions in parent regional model for area replaced by child model .....................................................................................................

6. Grid discretization and boundary conditions for child model ..........................................8

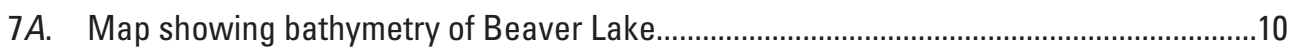

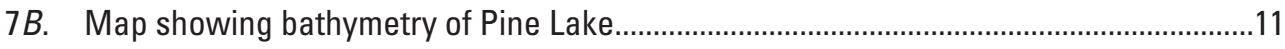

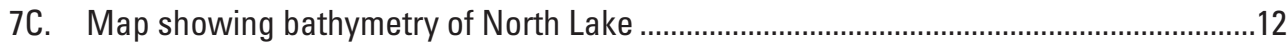

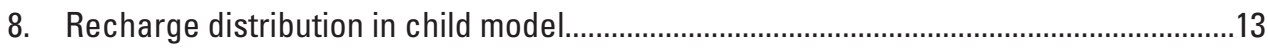

9. Map showing location of pumping wells in child model..................................................14

10. Graph showing aquifer-test analysis of drawdowns at three observation wells ............16

11. Distribution of horizontal hydraulic conductivity in child model, layers 1 and 2 .............17

12. Map showing locations of flow measurements ........................................................19

13. Child-model domain showing the simulated water-table elevation for the calibration run 
14. Graph showing simulated water budgets of Beaver, Pine, and North Lakes under base-case conditions

\section{Tables}

1. Summary of flow measurements in Chenequa area, Wisconsin

2. Comparison of measured to simulated values for calibration targets for

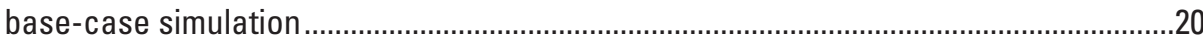

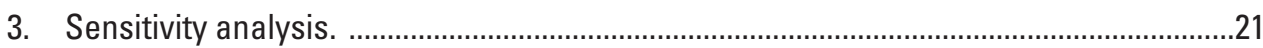

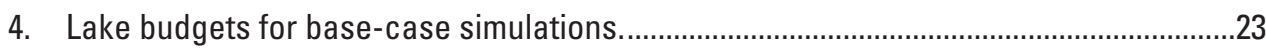

5. Simulated change to stage of Beaver, Pine, Cornell, and North Lakes and change to outflow from Beaver and Pine Lakes due to 5 years of dry weather conditions.

6. Simulated change to stage of Beaver, Pine, Cornell, and North Lakes and change to outflow from Beaver and Pine Lakes with test well pumped for 5 years at 47 gallons per minute and at 200 gallons per minute under average weather conditions.

7. Simulated change to stage of Beaver, Pine, Cornell, and North Lakes and change to outflow from Beaver and Pine Lakes with test well pumped for 5 years at 47 gallons per minute under dry weather conditions.

8. Simulated sources to test well pumped for 5 years at 47 gallons per minute (for average and dry weather conditions) and at 200 gallons per minute (for average weather conditions).

9. Simulated groundwater inflow to lakes under various pumping and weather conditions.

\section{Conversion Factors and Datums}

\begin{tabular}{|c|c|c|}
\hline Multiply & By & To obtain \\
\hline \multicolumn{3}{|c|}{ Length } \\
\hline foot $(\mathrm{ft})$ & 0.3048 & meter $(\mathrm{m})$ \\
\hline mile (mi) & 1.609 & kilometer $(\mathrm{km})$ \\
\hline \multicolumn{3}{|c|}{ Flow, precipitation, evaporation, and recharge rates } \\
\hline inch per year (in/yr) & 25.4 & millimeter per year $(\mathrm{mm} / \mathrm{yr})$ \\
\hline cubic foot per day $\left(\mathrm{ft}^{3} / \mathrm{d}\right)$ & 0.02832 & cubic meter per day $\left(\mathrm{m}^{3} / \mathrm{d}\right)$ \\
\hline gallon per minute (gal/min) & 0.06309 & liter per second $(\mathrm{L} / \mathrm{s})$ \\
\hline \multicolumn{3}{|c|}{ Hydraulic conductivity } \\
\hline foot per day (ft/d) & 0.3048 & meter per day $(\mathrm{m} / \mathrm{d})$ \\
\hline \multicolumn{3}{|c|}{ Transmissivity } \\
\hline foot squared per day $\left(\mathrm{ft}^{2} / \mathrm{d}\right)$ & 0.09290 & meter squared per day $\left(\mathrm{m}^{2} / \mathrm{d}\right)$ \\
\hline
\end{tabular}

Vertical coordinate information is referenced to the insert National Geodetic Vertical Datum of 1929 (NGVD 29).

Horizontal coordinate information is referenced to the North American Datum of 1983 (NAD 83) and the Albers projection. 


\title{
Application of the Local Grid Refinement Package to an Inset Model Simulating the Interaction of Lakes, Wells, and Shallow Groundwater, Northwestern Waukesha County, Wisconsin
}

\author{
By D.T. Feinstein, C.P. Dunning, P.F. Juckem, and R.J. Hunt
}

\section{Abstract}

Groundwater use from shallow, high-capacity wells is expected to increase across southeastern Wisconsin in the next decade (2010-2020), owing to residential and business growth and the need for shallow water to be blended with deeper water of lesser quality, containing, for example, excessive levels of radium. However, this increased pumping has the potential to affect surface-water features. A previously developed regional groundwater-flow model for southeastern Wisconsin was used as the starting point for a new model to characterize the hydrology of part of northwestern Waukesha County, with a particular focus on the relation between the shallow aquifer and several area lakes. An inset MODFLOW model was embedded in an updated version of the original regional model. Modifications made within the inset model domain include finer grid resolution; representation of Beaver, Pine, and North Lakes by use of the LAK3 package in MODFLOW; and representation of selected stream reaches with the SFR package. Additionally, the inset model is actively linked to the regional model by use of the recently released Local Grid Refinement package for MODFLOW-2005, which allows changes at the regional scale to propagate to the local scale and vice versa.

The calibrated inset model was used to simulate the hydrologic system in the Chenequa area under various weather and pumping conditions. The simulated model results for base conditions show that groundwater is the largest inflow component for Beaver Lake (equal to 59 percent of total inflow). For Pine and North Lakes, it is still an important component (equal, respectively, to 16 and 5 percent of total inflow), but for both lakes it is less than the contribution from precipitation and surface water. Severe drought conditions (simulated in a rough way by reducing both precipitation and recharge rates for 5 years to two-thirds of base values) cause correspondingly severe reductions in lake stage and flows. The addition of a test well south of Chenequa at a pumping rate of $47 \mathrm{gal} /$ min from a horizon approximately 200 feet below land surface has little effect on lake stages or flows even after 5 years of pumping. In these scenarios, the stage and the surface-water outflow from Pine Lake are simulated to decrease by only 0.03 feet and 3 percent, respectively, relative to base conditions. Likely explanations for these limited effects are the modest pumping rate simulated, the depth of the test well, and the large transmissivity of the unconsolidated aquifer, which allows the well to draw water from upstream along the bedrock valley and to capture inflow from the Bark River. However, if the pumping rate of the test well is assumed to increase to $200 \mathrm{gal} / \mathrm{min}$, the decrease in simulated Pine Lake outflow is appreciably larger, dropping by 14 percent relative to base-flow conditions.

\section{Introduction}

Shallow high-capacity wells will likely continue to be drilled across southeastern Wisconsin in the next decade (2010-20) for numerous purposes, including new water supplies for residential and business growth and blending of shallow water with deeper water of lesser quality-for example, water with excessive concentrations of radium-in order to improve overall quality of the drinking-water supply. Pumping wells, particularly where they intercept substantial groundwater flow to surface water, have the potential to affect lake levels; the groundwater inflow to wetlands, creeks, and rivers; and water temperature. The effect of pumping can be pronounced because in many hydrogeologic settings, and particularly in much of southeastern Wisconsin, groundwater is in direct hydraulic connection with lakes, wetlands, and streams. Quantifying hydrologic changes resulting from groundwater pumping and assessing the effect on hydrologic and biologic resources is a challenge faced by many communities and lake organizations across southeastern Wisconsin.

The U.S. Geological Survey and cooperating organizations, such as the Wisconsin Geological and Natural History Survey (WGNHS) and the Southeastern Wisconsin Regional Planning Commission (SEWRPC), have previously worked 
together to develop a regional understanding of the hydrology of southeastern Wisconsin. This work has taken the form of geologic mapping, groundwater-flow modeling, quantifying and predicting demand on surface and groundwater resources, and field investigations. A southeastern Wisconsin regional groundwater-flow model was developed as part of this work to serve as a framework for hydrologic studies addressing a wide range of water-supply concerns. In a recent extension of this longstanding research, the USGS joined with the Southeastern Wisconsin Regional Planning Commission and the Village of Chenequa in work funded by the Wisconsin Department of Natural Resources under the Chapter NR 190 Lake Management Planning Grant Program, to characterize the hydrology of part of northwestern Waukesha County (fig. 1), with a particular focus on the relation between the shallow aquifer and area lakes. The specific objectives of this study were to

1. improve the overall understanding of the dynamics of the shallow aquifer in northwestern Waukesha County near Chenequa;

2. evaluate the role of groundwater on maintaining lake levels in northwestern Waukesha County by using Beaver, Cornell, North, and Pine Lakes as examples;

3. develop hydrologic budgets for the area; and

4. develop databases and a refined groundwater-flow model that may have future benefit to researchers and waterresource professionals in the northwestern Waukesha County area.
The steps undertaken to achieve the objectives were

- compilation of existing hydrologic data;

- limited collection of surface-water-flow data to support model development and calibration;

- development of an inset MODFLOW model originating from the regional groundwater-flow model and implementing the recently released Local Grid Refinement package for MODFLOW-2005 (Mehl and Hill, 2005);

- calibration of the inset model to available head and flow targets;

- analysis of the results of the base-case simulation, focusing on the water budgets of the Chenequa-area lakes; and

- simulation of selected scenarios involving changes in climatic conditions and local pumping rates.

The complexity of the inset model increased compared to that of the existing regional model but was commensurate with the extent of the dataset in the local area. Changes to model layering and zonation of hydrologic parameter values were based on interpretation of available data.

This report presents the findings from the above-mentioned study and describes the interrelations within the hydrologic system simulated in this study, which encompasses the lakes, streams, and shallow groundwater system.

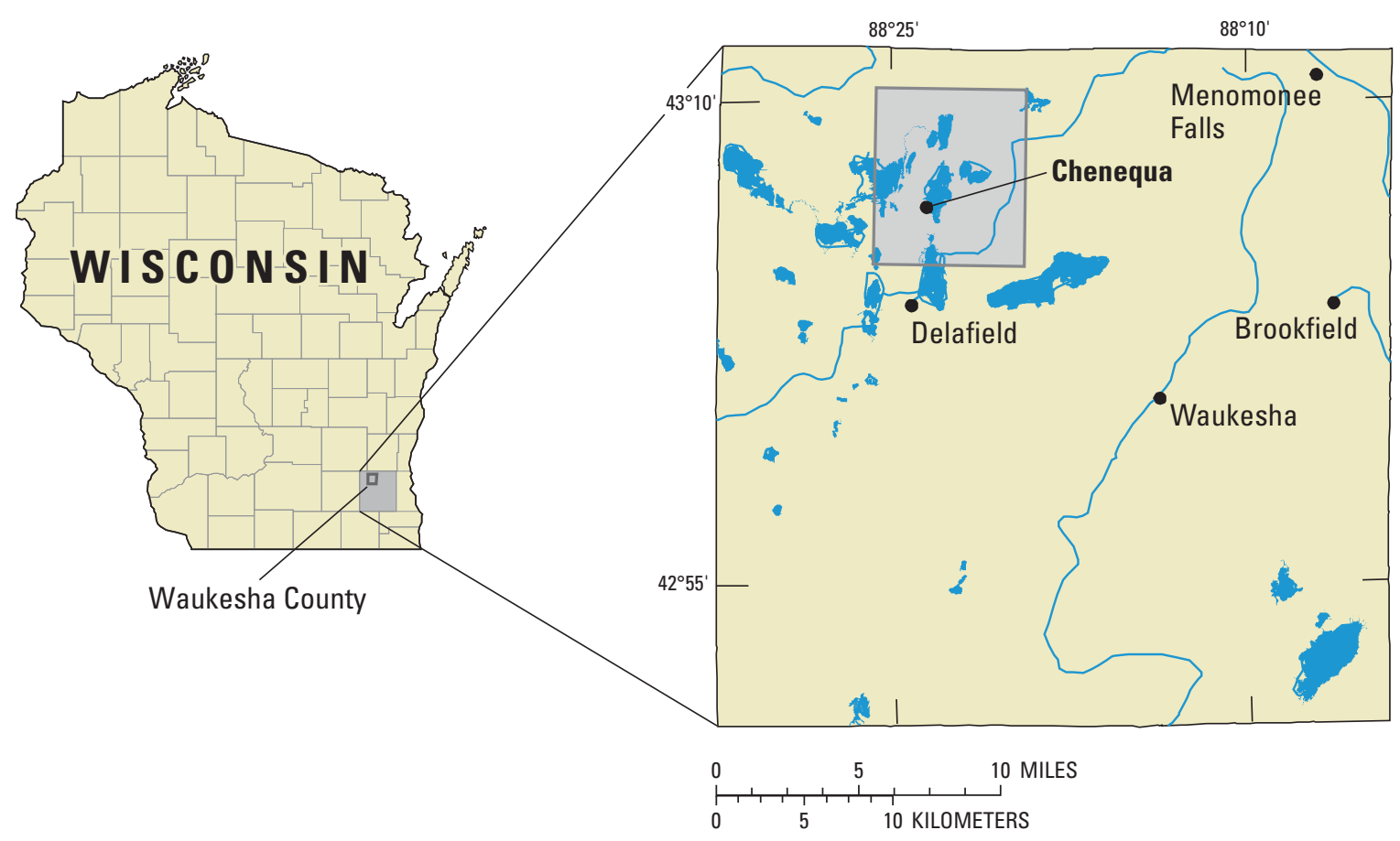

Figure 1. Location of study area, near Chenequa, Waukesha County, Wisconsin. 


\section{Southeastern Wisconsin Background Regional Model}

The inset model is based on the previously developed three-dimensional finite-difference MODFLOW groundwater-flow model of the seven-county region of southeastern Wisconsin administered by the SEWRPC. The Southeastern Wisconsin background regional model (hereafter called the background regional model) was constructed cooperatively by the WGNHS and the USGS. Readers are directed to Feinstein, Eaton, and others (2005) and Feinstein, Hart, and others (2005) for detailed explanation of the development and application of the background regional model.

The hydrogeologic setting of the Chenequa area is typical of the part of southeastern Wisconsin represented in the background regional model. Crystalline bedrock of Precambrian age underlies the region; sandstone and carbonate units of Cambrian and Ordovician age overlie the crystalline bedrock (fig. 2). These units consist of the Mount Simon Formation, Eau Claire Formation, Wonewoc Formation, Tunnel City Group, Trempealeau Group, Prairie du Chien Group, and St. Peter Formation. Directly overlying the St. Peter Formation is the Sinnipee Group and Maquoketa Formation, a sequence with generally low vertical hydraulic conductivity, that isolates glacial and carbonate aquifers above (Silurian and younger) from the sandstone-dominated deep aquifer system below (Ordovician and older). The near-surface stratigraphy of southeastern Wisconsin consists of unlithified, glacially derived Pleistocene and Holocene deposits. Owing to the eastward dip of the consolidated bedrock stratigraphic units in southeastern Wisconsin, progressively younger bedrock units pinch out to the west. The Maquoketa Formation is present over most of Waukesha County but pinches out in areas of the southern and northwestern parts of the county; it is present only under part of the Chenequa study area. Where the Maquoketa Formation is absent, the shallow, unlithified deposits are in better hydraulic connection to the underlying sandstone aquifers, but resistive layers in the Sinnipee Group still limit somewhat the amount of vertical exchange.

\section{Child Model Embedded in Parent Regional Model}

In the field of groundwater modeling, one-way coupling from a coarse regional model to a local and refined model grid is commonly called telescopic mesh refinement (TMR) and is most often accomplished by using some form of interpolation of either heads or fluxes, or both, from the coarse grid onto the boundaries of the refined grid (for example, Buxton and Reilly, 1986; Ward and others, 1987; Leake and Claar, 1999; Davison and Lerner, 2000; Hunt and others, 2001). This approach is fairly straightforward and works well for many problems. The one-way coupling, however, does not allow for feedback from the refined grid (hereafter called the child grid) to the coarse grid (hereafter called the parent grid). Therefore, after running both models, the modeler must determine whether heads along and fluxes across the interfacing boundaries are consistent for both models (Leake and Claar, 1999, p. 5-7). If they do not match, then the modeler must make adjustments by trial and error: there is no formal mechanism for adjusting the models to achieve better agreement. For this reason, TMR methods generally lack numerical rigor and sometimes lead to significant, often undetected errors (Mehl and Hill, 2002a,b).

A numerically more rigorous method that ensures consistency of heads and fluxes between the two grids-local grid refinement (LGR) - is an iteratively coupled method that links the parent and child grids in a way that provides feedback from the child grid to the parent grid, thus allowing two-way communication between the grids. Two-way iterative coupling is used to ensure that the models have consistent boundary conditions along their adjoining interface. Solutions with feedback can be achieved either through iteration or through simultaneous solution schemes. LGR couples the models by means of shared nodes; that is, the grids are constructed such that nodes of the parent grid are coincident with selected boundary nodes of the child grid. LGR uses the iteratively coupled shared-node method of local grid refinement developed and tested by Mehl and Hill (2002 a,b; 2003; 2004) and Mehl (2003).

\section{Inset Model Grid Refinement}

The first modification in creating the inset model for the Chenequa study was made to the entire domain of the southeastern Wisconsin background regional model. The original regional model was developed with MODFLOW 96 and was modified to run under MODFLOW-2005. The lower 8 layers of the initially 18-layer background regional model-those constituting the sandstone-dominated deep aquifer system (fig. 3) - were combined into a single confined layer with representative bulk hydraulic properties. These bulk properties preserve the spatial variation of the transmissivity and storage capacity of the deep aquifer system. This simplification was appropriate because the primary objective of the inset model is to simulate the interaction between the shallow groundwater system and area lakes. Given that confining units within the Maquoketa Formation and Sinnipee Group hydraulically separate the deep aquifer system from the shallow aquifers in this area, the shallow modeling results are largely insensitive to a detailed representation of the internal flow dynamics of the deep aquifer system. The new refined version of the regional model is hereafter referred to as the "parent regional model." Layers 1 through 10 are the same in both versions of the regional models, but layer 11 of the parent regional model combines layers 11 through 18 of the background model. The inset model embedded inside the parent regional model also represents the deep aquifer system with the single layer 11 (fig. 3B). 


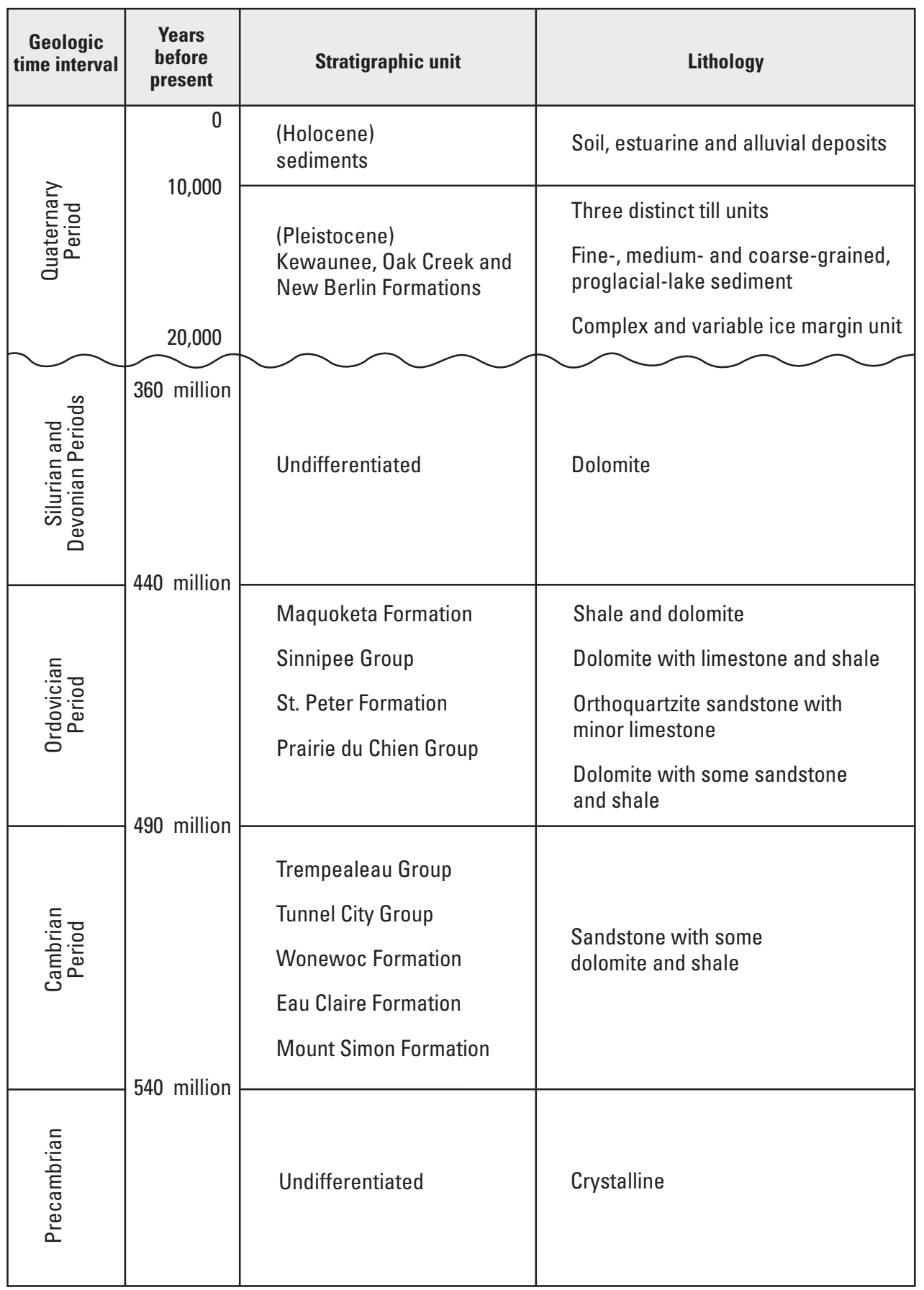

Figure 2. Stratigraphic section for southeastern Wisconsin (modified from Brown and Eaton, 2002). 
$\boldsymbol{A}$

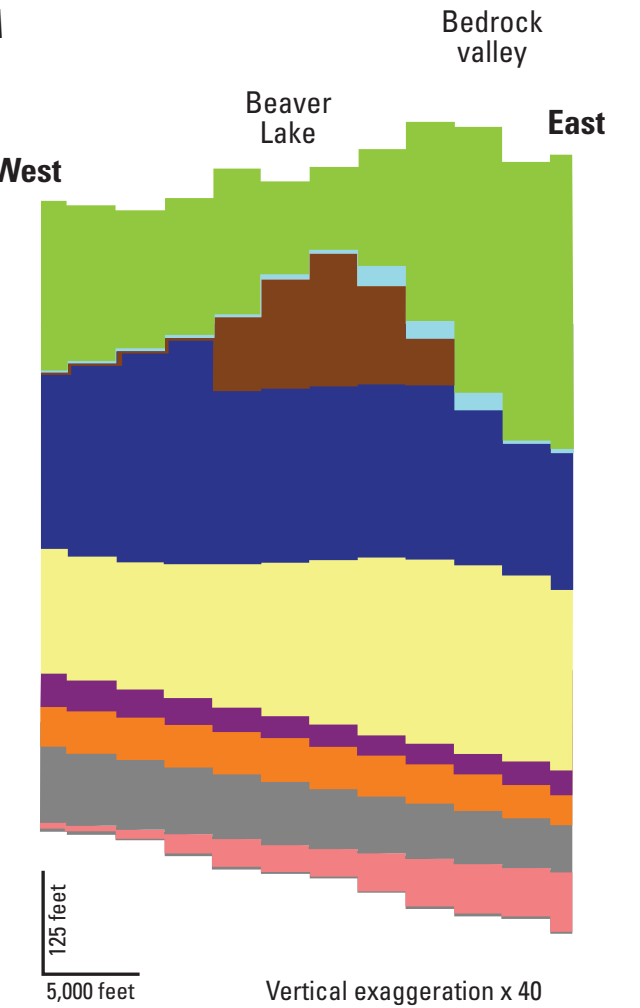

B

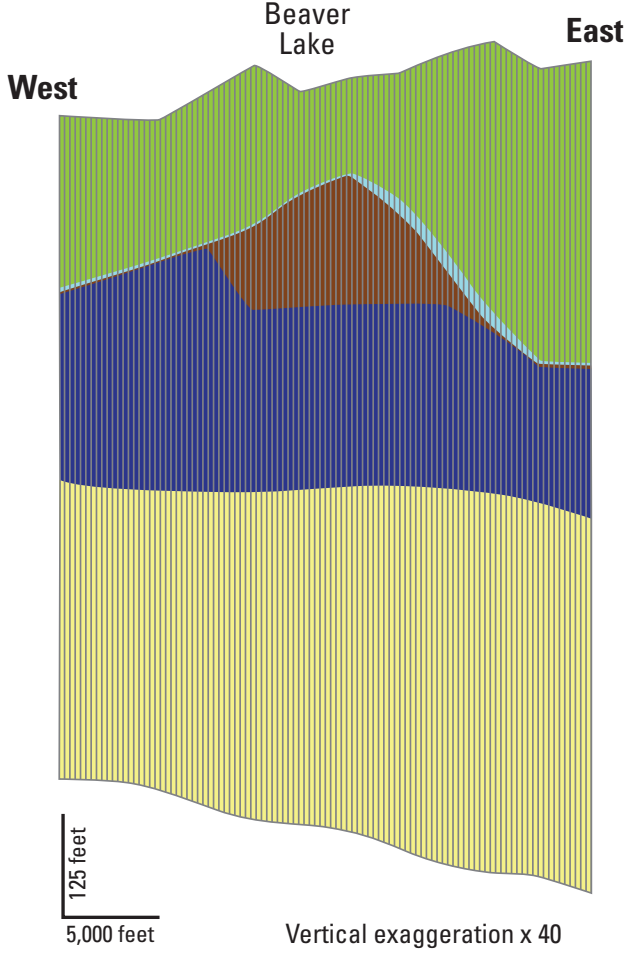

\section{EXPLANATION}

Glacial deposits (layers 1-2)

Silurian dolomite (layers 3-6)

Maquoketa Formation (layers 7-8)

Sinnipee Group (layers 9-10)

St. Peter Formation and Prairie du Chien Group (layer 11)

Trempealeau/Tunnel City Groups (layer 12)

Wonewoc Formation (layer 13)

Eau Claire Formation (layer 14)

Mount Simon Formation (layers 15-18)

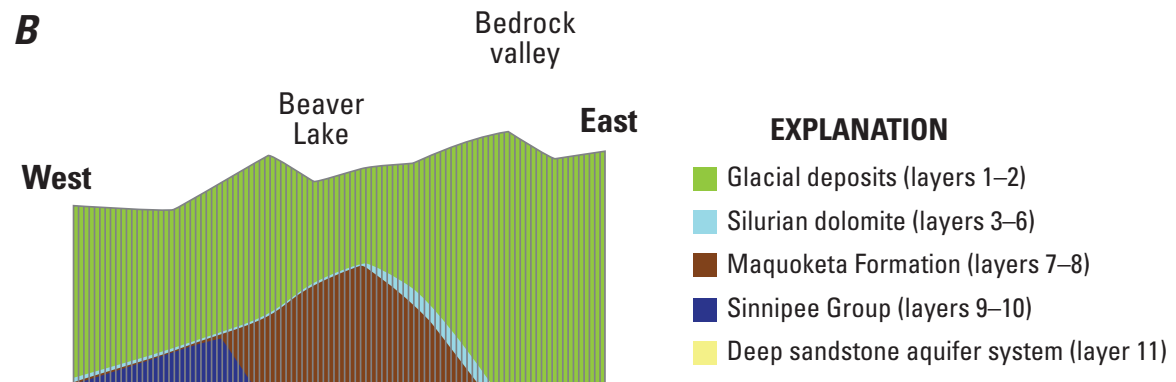

Figure 3. Model layering in example east-west section. $A$, Layering in background regional model. $B$, Layering in parent regional and child model. (The comparison of model layering shows that the deep sandstone aquifer system is represented by eight model layers in the background regional model but is represented by a single layer in the parent regional and child models. The east/west section contains the entire east-west extent of the child model, which consists of 100 columns, each $277.78 \mathrm{ft}$ wide. The section bisects the north-south extent of Beaver Lake and further to the east intersects a northeast-southwest-trending bedrock valley. See fig. 4 for the trace $\left(A-A^{\prime}\right)$ of the example section.) 
In both the parent regional and child models, Layers 1 through 10 maintain the hydrostratigraphic sequence used in the background regional model (fig. $3 B$ ). The top two layers represent the unlithified glacial material, layer 3 represents Pennsylvanian and Mississippian bedrock (absent in southeastern Wisconsin and therefore this layer is given a negligible thickness), layers 4 through 6 represent the Silurian dolomite, layers 7 and 8 represent the Maquoketa Formation, and layers 9 and 10 represent the Sinnipee Group. In general, the glacial deposits can act as an unconfined aquifer or a confining unit, the Silurian dolomite serves as an unconfined or semi-confined aquifer, the Maquoketa Formation is a confining unit, and the Sinnipee Group can act as a confining unit or contribute transmissivity to the underlying confined, deep aquifer system. Descriptions of the properties of these units, including thickness and permeability, can be found in Feinstein, Eaton and others, 2005.
The inset (child) model constructed for the Chenequa study is derived from the parent regional model. The child model was sized to include Beaver, Pine, and North Lakes (lakes of primary interest to the study), as well as some distant surface-water boundaries, while keeping the model size relatively compact (fig. 4). The child model grid was refined by use of a TMR approach similar to one described by Ward and others (1987). The TMR routine was run with Groundwater Vistas (Rumbaugh and Rumbaugh, 2007). In the parent regional model, grid spacing is 2,500 ft (fig. 5); in the child model, the grid is one-ninth the spacing, or $277.8 \mathrm{ft}$ on a side. Thus, every parent regional model node is represented by 81 nodes in the child model. The layering of the child model is identical to the layering in the parent model. The child model has 118 rows and 100 columns (fig. 6). With 118 rows, 100 columns, and 11 layers, the child model has 129,800 cells, all of which are active. As a result of smaller grid spacing, the

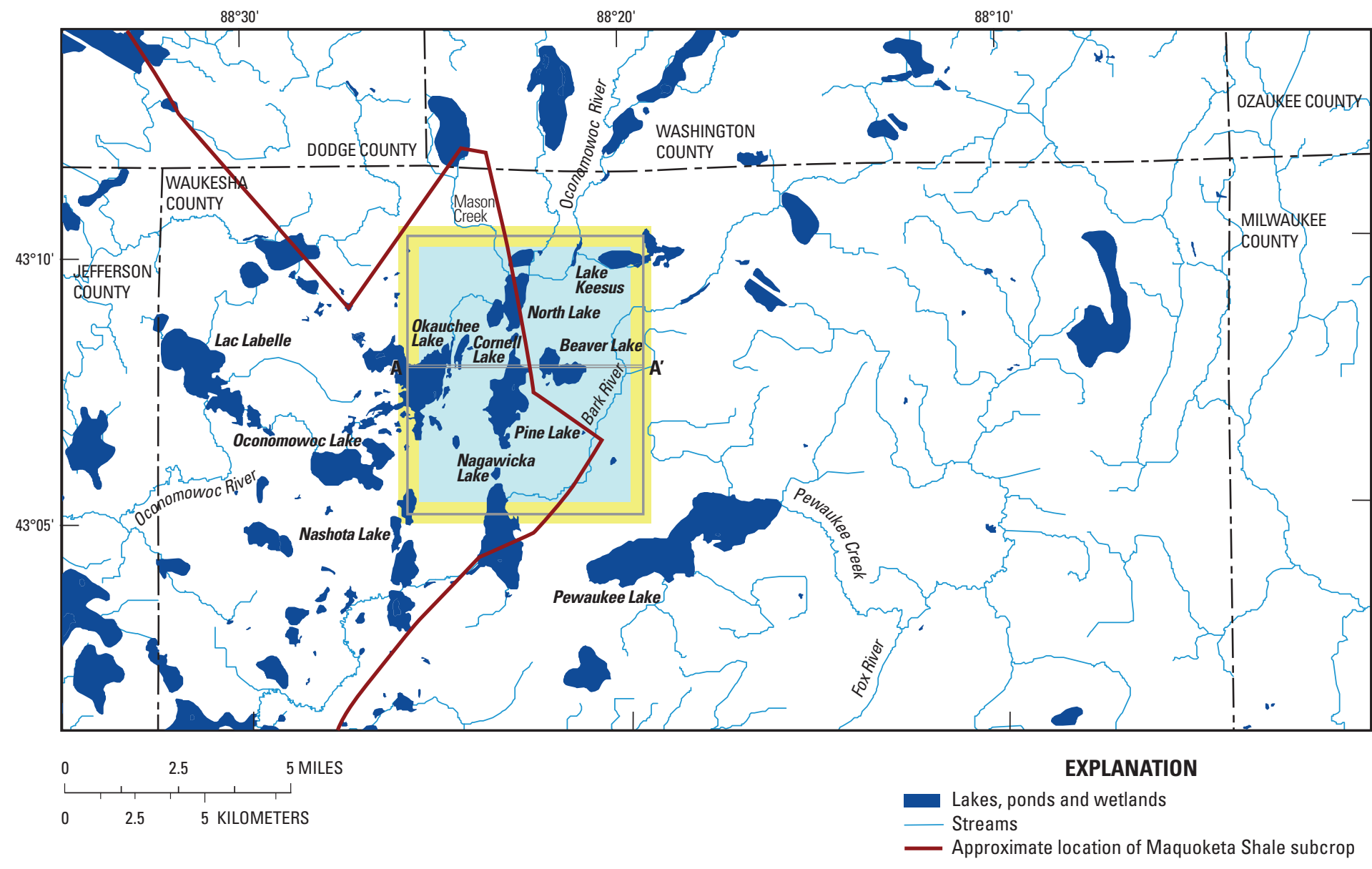

Figure 4. Location of the child model centered on Beaver, Pine, Cornell, and North Lakes. (The brown line is the westernmost extent of the Maquoketa Formation confining unit that separates the shallow and deep systems where it is present. The yellow perimeter corresponds to the parent regional model cells that are shared with the child model. The child model extends half the distance into the yellow perimeter. The $A-A^{\prime}$ trace shows the location of the sections in fig. 3.) 


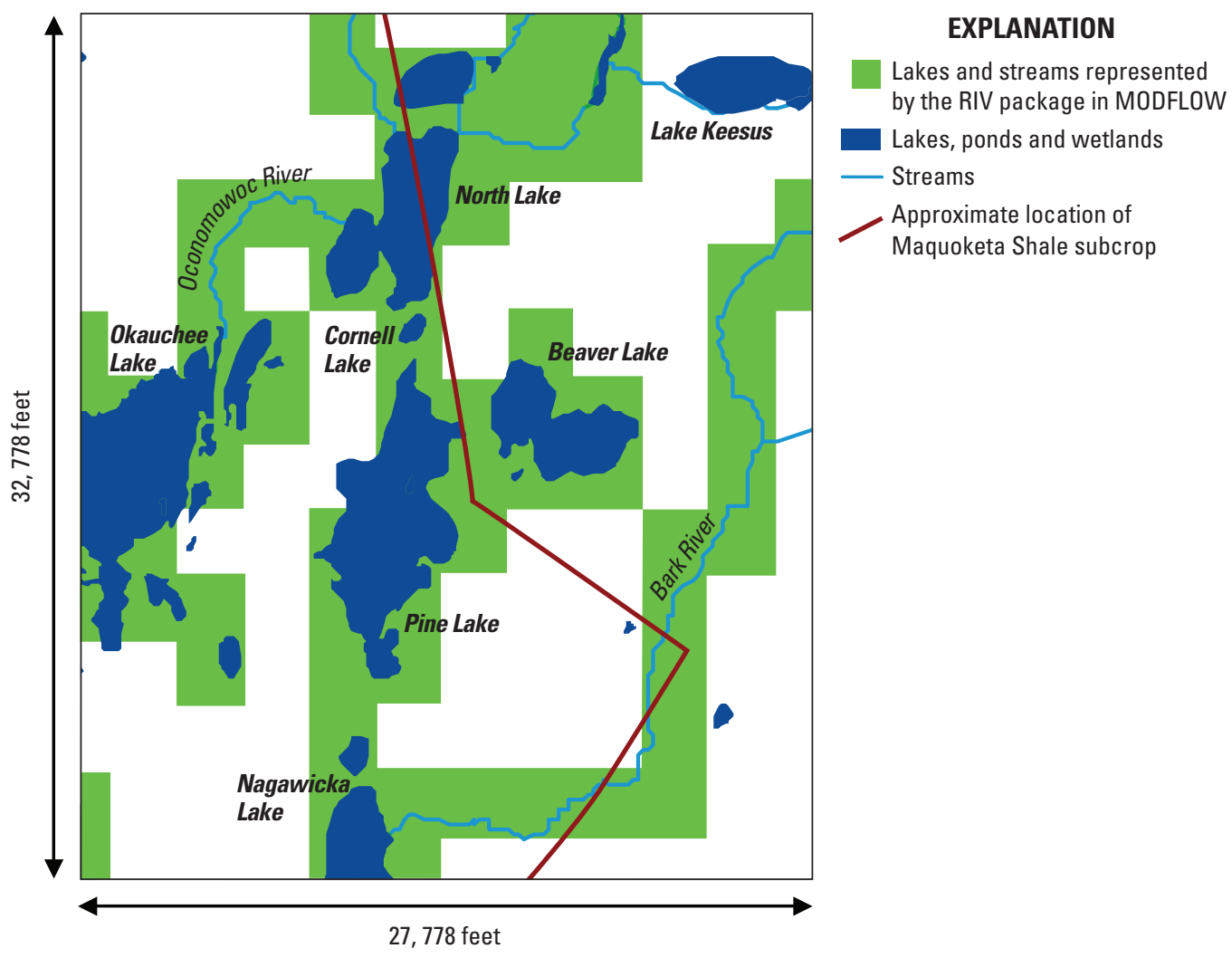

Figure 5. Original discretization and boundary conditions in parent regional model for area replaced by child model. (Cells in parent regional model are 2,500 feet on a side.)

surface-water features, pumping stresses, and the hydraulichead distribution are represented more accurately in the child model than in the regional model. Therefore, interactions between streams and lakes, as well as three-dimensional flows near those features, are also simulated more accurately.

In addition to the greater resolution built into its grid, the child model is designed to more actively portray surfacewater features. Selected streams were converted from the MODFLOW River Package (McDonald and Harbaugh, 1988), shown in figure 5, to the more sophisticated Stream Routing (SFR1) Package (Prudic and others, 2004), shown in figure 6. The latter allows accounting of streamflow and limits the amount of water a stream can lose to the aquifer to the amount of water captured upstream. In the child model, SFR cells are used to represent stream segments connecting the Chenequa lakes and streams entering and exiting North Lake, whereas the River Package is used to simulate the Bark River and parts of Lakes Okauchee and Nagawicka (fig. 6) because neither stream routing nor the ability to control infiltration quantities was required for these features.

A final refinement in the child model was the conversion of Beaver, Pine, and North Lake from the MODFLOW River Package (fig. 5) to the more sophisticated Lake (LAK3) Package (Merritt and Konikow, 2000) (fig. 6). This package provides for active model grid cells representing the aquifer adjacent to and beneath lakes; these active cells can simulate exchange of water between an aquifer and a lake at a rate determined by relative heads and by conductances that are based on grid-cell dimensions, hydraulic conductivities of the aquifer material, and user-specified precipitation, evaporation, and leakance distributions that represent the resistance to flow through the material of the lakebed (fig. 6). The use of the LAK3 package allows the lake stages to be calculated (instead of specified) and the complete lake water budget to be evaluated.

\section{Input to the Parent Regional Model}

The parameterization of the surface-water network, hydraulic conductivity of unconsolidated and bedrock units, and the distribution of recharge in the parent regional model is identical to the input to the background regional model described in Feinstein, Eaton, and others (2005). No changes were made to the regional input except to assign an average hydraulic conductivity to the cells in the single layer that represents the units composing the deep sandstone aquifer (in order to preserve the combined transmissivity assigned the multiple layers in the background regional model). 


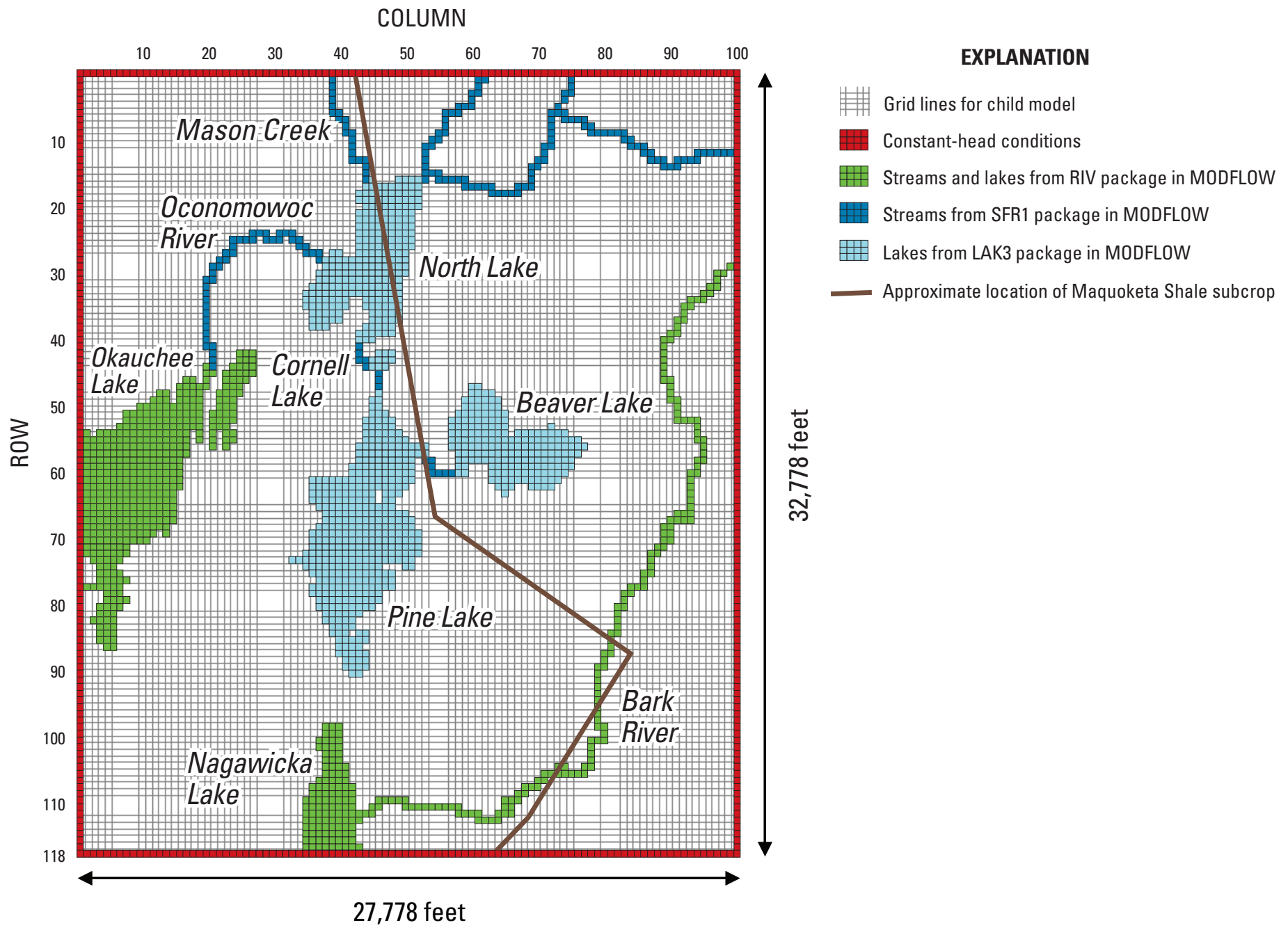

Figure 6. Grid discretization and boundary conditions for child model. (Cells in child model are 277.8 feet on a side.)

\section{Temporal Discretization of the Models}

The parent regional and child models incorporate the deep pumping which, since the late 19th century, created and has gradually enlarged a regional cone of depression under southeastern Wisconsin in the deep sandstone aquifer system (Feinstein, Hart, and others, 2005). The effects of shallow pumping in the Silurian dolomite and glacial deposits, although less dramatic and more local in terms of drawdown, also are simulated by the models. For the purposes of this analysis, the historical rates of shallow and deep pumping used originally in the 18-layer background regional model to simulate conditions for multiple intervals between 1864 and 1990 were input to the 11-layer parent regional model. As in the case of the background regional model, the parent regional model was used first to simulate steady-state predevelopment conditions, and then transient results were obtained for the 1864 to 1990 period starting from the simulated steady-state condition. Both the steady-state and transient results are similar to the original results reported by Feinstein, Hart, and others (2005) for the background regional model. The parent regional model was then linked to the embedded child model by using the LGR procedure enabled by MODFLOW-2005 (Mehl and Hill, 2005). A 20-year runup period was simulated, beginning from 1990 parent regional model results and using the same discharge rates originally assigned the background regional model for the 1991-2000 interval. This hypothetical transient runup period is needed to allow the model to react to the linking of the two models and reach a new set of stable conditions (it does not correspond to an actual period of time). Finally, an additional 5-year period was added to the end of the linked transient simulation in order to investigate the interactions of groundwater and the Chenequa-area lakes under several pumping, recharge, precipitation, and evaporation scenarios. The 1991-2000 pumping rates were sustained for this transient 5-year observation period. 


\section{River Package Input to the Child Model}

Within the child model, the Bark River and outlying lakes (Nagawicka Lake and Okauchee Lake) were represented by means of the MODFLOW RIV package. Stage was specified on the basis of elevations recorded on topographic maps. In the case of the Bark River, the topographic elevations were used to determine the slope of the stream surface within the child grid. The hydraulic conductivity of the bed of the Bark River was assumed to be $1 \mathrm{ft} / \mathrm{d}$, and the bed thickness was assumed to be $1 \mathrm{ft}$. The hydraulic conductivity and thickness of the lake beds was assumed to be $0.1 \mathrm{ft} / \mathrm{d}$ and $1 \mathrm{ft}$, respectively.

\section{Streamflow Routing Package (SFR1) Input to the Child Model}

The MODFLOW SFR1 package allows stream stage to be calculated as part of the model solution. The code also routes flow from upgradient to downgradient stream nodes along the network, allowing the model to keep track of the streamflow and the surface water available to be captured, for example, by pumping. The channel connections between the Chenequa-area lakes were represented by SFR nodes. In addition, the flow in tributaries to North Lake within the child model domain (including Mason Creek and stretches of the Oconomowoc River) was handled by the SFR1 package. In each case the hydraulic conductivity of the lakebed was assumed to be $1 \mathrm{ft} / \mathrm{d}$ and the bed thickness to be $1 \mathrm{ft}$.

The slopes of the streambeds input to the SFR1 package are based on topographic contours reported on U.S. Geological Survey maps (Stonebank and Merton topographic quadrangles, 1959, scale 1:24,000). The streambed elevations at the outlets of Beaver, Pine, Cornell, and North Lakes are estimated to be between 0.1 and $2 \mathrm{ft}$ below the target lake stage and are implemented in the child model so that stream depth increases downstream.

\section{Lake Package Input to the Child Model}

The geometries of the child-model layers and model cells representing Beaver, Pine, and North Lakes are based on information in historical bathymetric maps (fig. 7). The hydrologic characteristics of the lake model cells were assigned by using existing data and were refined through the calibration process. Of particular importance are the conductance values assigned to the lakebeds because they control the flow between the groundwater system and the water bodies. Beaver, Pine, and North Lakes were assigned higher conductance values under the shoreline (littoral zone) than under the interior of the lake (profundal zone). The littoral zone was defined to be one cell wide, equivalent to $278 \mathrm{ft}$.

Also important are the stage-discharge relations assumed for each lake. Observed outflows from the lakes vary widely in response to season and stage. Measured streamflow out of
Beaver Lake (table 1) varied from $107,136 \mathrm{ft}^{3} / \mathrm{d}$ on June 7 , 2007 , to zero on July 17,2007 , to $86,400 \mathrm{ft}^{3} / \mathrm{d}$ on September 27, 2007. Measured streamflow out of Pine Lake (table 1) varied from $254,018 \mathrm{ft}^{3} / \mathrm{d}$, zero, and $5,357 \mathrm{ft}^{3} / \mathrm{d}$ on the same successive dates. Given the scarcity of flow data, it was necessary to base an average outflow condition for these lakes on the average of the three available measurements. This discharge was assumed to correspond to the long-term average elevation of the lakes as shown on the USGS topographic maps for the Chenequa area (Stonebank and Merton quadrangles, 1959, scale 1:24,000): $909 \mathrm{ft}$ elevation for Beaver Lake, $900 \mathrm{ft}$ elevation for Pine Lake, and $896 \mathrm{ft}$ elevation for North Lake; Cornell Lake elevation was estimated as the average of the stages of Pine and North Lakes. These levels were selected because they are consistent with stream input also drawn from topographic maps. However, data collected for Beaver and Pine Lakes in 2006-8 indicated higher levels, averaging $1 \mathrm{ft}$ higher in the case of Beaver Lake and between 2 and $3 \mathrm{ft}$ in the case of Pine Lakes (Jeffrey Kante, Village of Chenequa, written commun., February 9, 2009). These recent data indicate a degree of uncertainty in lake levels, possibly connected to climate variability.

Input to the LAK3 package also includes precipitation and evaporation to the lake surfaces. These values were assumed to be 32 and $29 \mathrm{in} / \mathrm{yr}$, respectively, on the basis of average long-term observations in northwestern Waukesha County (Linsley and others, 1982, p. 78 for precipitation rate and p. 154 for evaporation rate). The long-term average rate of overland flow to the lakes was assumed to be negligible because of the generally coarse soils in the area, so it was set to zero in the model input.

\section{Recharge Input to the Child Model}

Recent research by the Wisconsin Geological and Natural History Survey (Hart and others, 2008) involving a GISbased soil-water-balance model (Westenbroek and others, 2010) produced a detailed recharge distribution over time for all of southeastern Wisconsin including the Chenequa area. This approach, however, is partially unconstrained in that it encompasses only the soil zone and therefore does not track or integrate infiltration out of the soil zone to surface-water features where flow measurements are made (Westenbroek and others, 2010). The groundwater-flow model constructed for the Chenequa-area study does integrate upgradient recharge at surface-water features, so it was used to constrain a multiplier applied to the spatial recharge distribution of Hart and others (2008). The Hart and others pattern for the child-model domain was scaled so as to agree with the average recharge rate input for the Chenequa area in the background regional model $(8.5 \mathrm{in} / \mathrm{yr})$. Around this average recharge rate of $8.5 \mathrm{in} /$ $\mathrm{yr}$, recharge in the child model varies between a low of $3.9 \mathrm{in} /$ $\mathrm{yr}$ and a high of $19.5 \mathrm{in} / \mathrm{yr}$. (fig. 8). The higher values reflect the presence of sandy soils over much of the area. No recharge was applied to the lakes in the child model. 


\section{A. Beaver Lake}

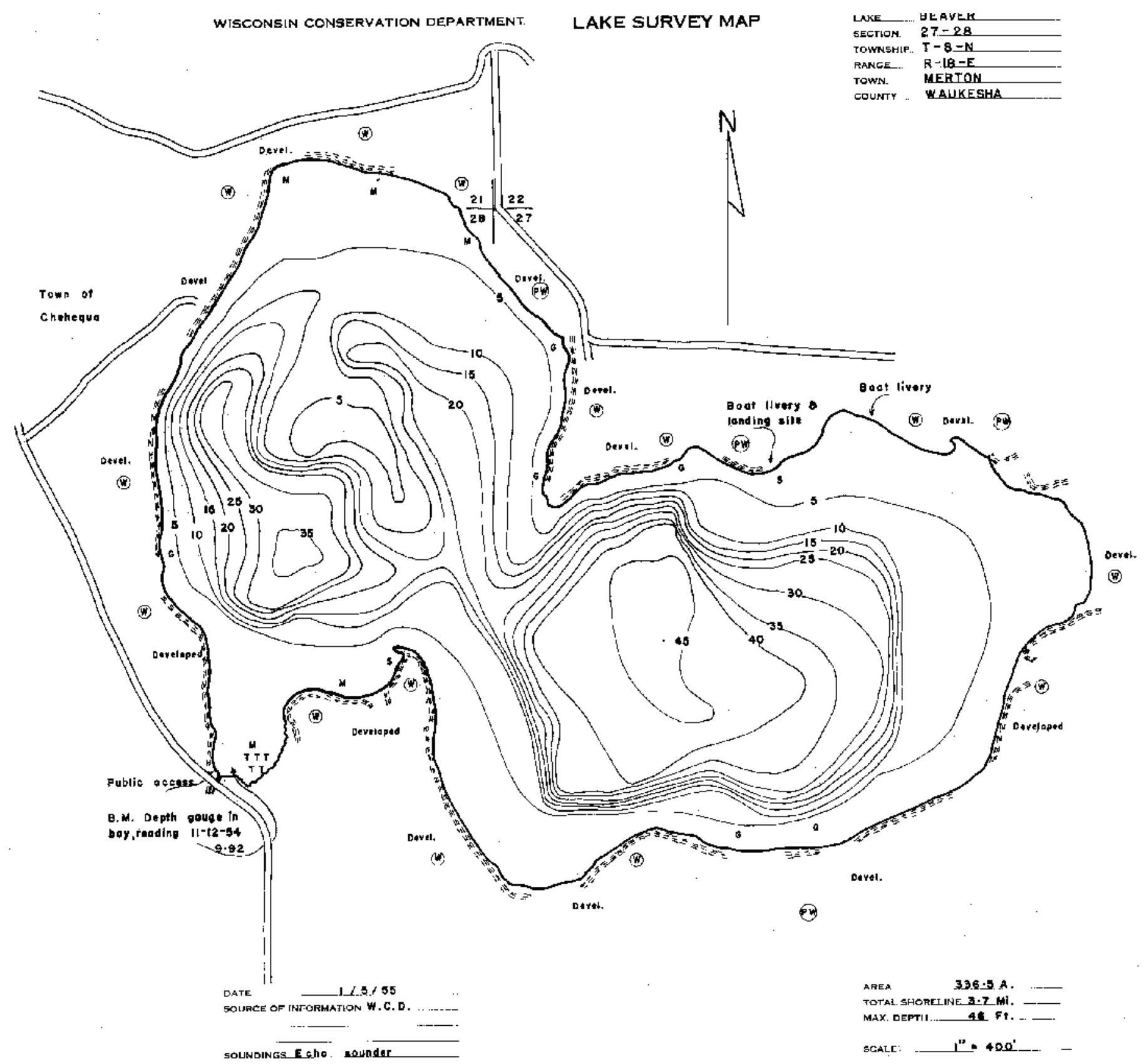

Figure 7A. Bathymetry of Beaver Lake (from Wisconsin Conservation Department, 1941 and 1955). 


\section{B. Pine Lake}

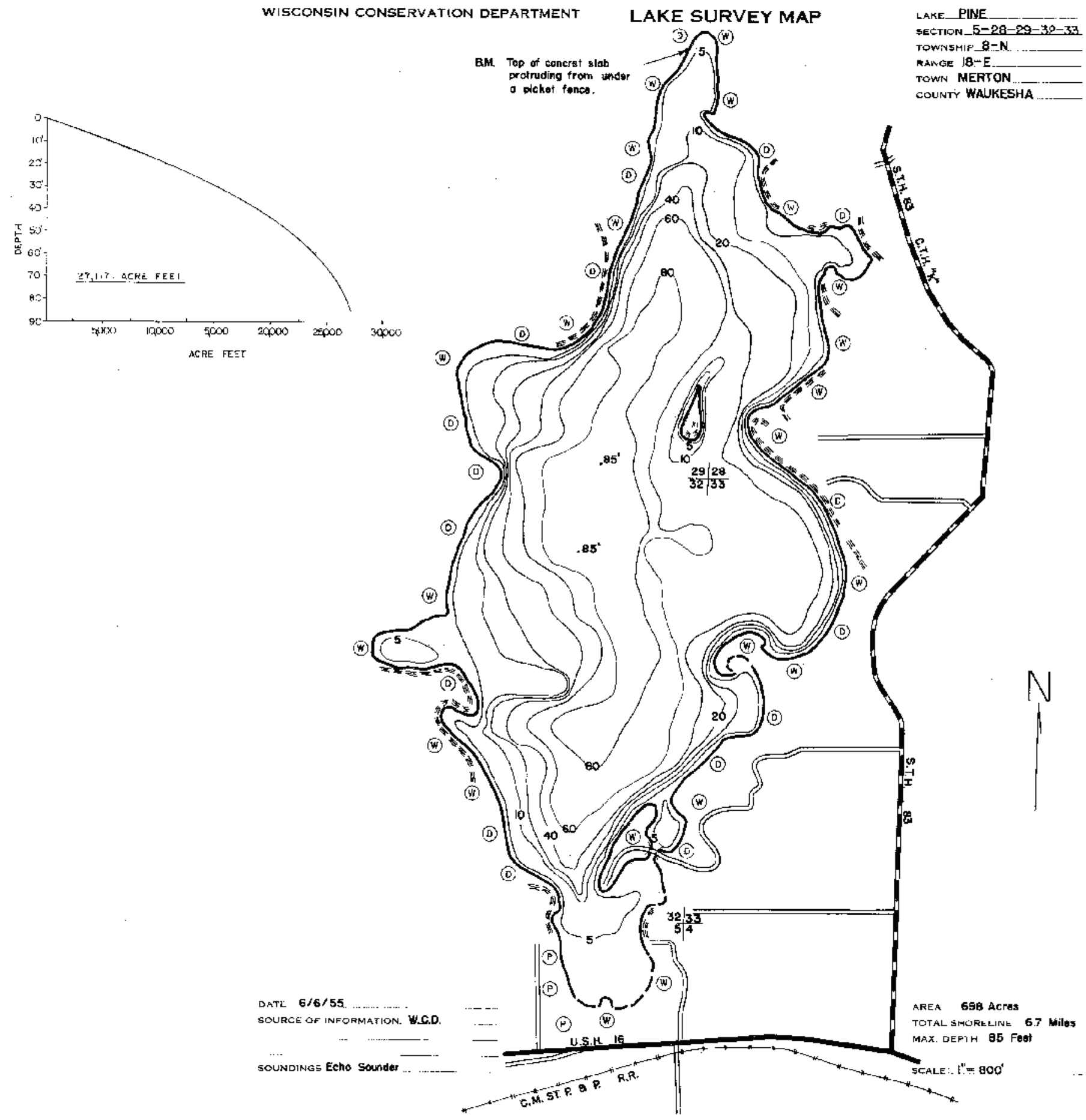

Figure 7B. Bathymetry of Pine Lake (from Wisconsin Conservation Department, 1941 and 1955). 


\section{North Lake}

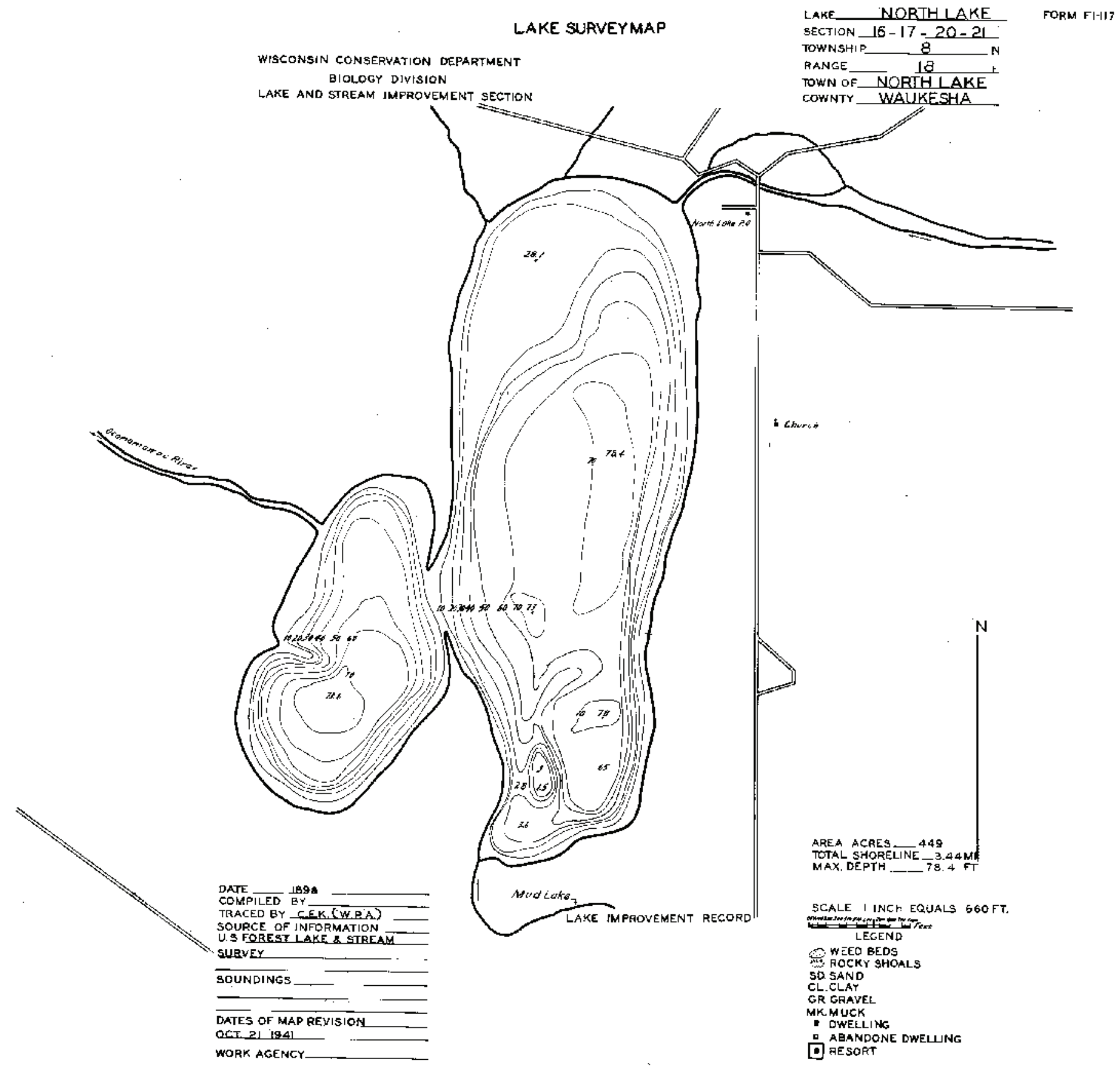

Figure 7C. Bathymetry of North Lake (from Wisconsin Conservation Department, 1941 and 1955). 
Table 1. Summary of flow measurements in Chenequa area, Wisconsin.

[Site locations are shown in fig. 12; - , not measured]

\begin{tabular}{llrrr}
\hline \multirow{2}{*}{$\begin{array}{l}\text { Site } \\
\text { number }\end{array}$} & \multicolumn{1}{c}{ Site name } & \multicolumn{2}{c}{ Measured streamflow, in cubic feet per day, by date } \\
\cline { 3 - 5 } & & $\mathbf{6 / 7 / 2 0 0 7}$ & $\mathbf{7 / 1 7 / 2 0 0 7}$ & $\mathbf{9 / 2 7 / 2 0 0 7}$ \\
\hline 1 & Beaver Lake outlet at Hwy 83 & 107,136 & 0 & 86,400 \\
2 & Pine Lake outlet at Cty Hwy K & 254,018 & 0 & 5,357 \\
3 & Bark River at Dorn Road near Merton & $1,676,160$ & $1,054,080$ & $1,667,520$ \\
4 & Bark River at Nagawicka Road at Delafield & $2,246,400$ & $1,296,000$ & $2,073,600$ \\
5 & Lake Keesus outlet at Whitcomb Road & 155,520 & 19,872 & 117,504 \\
6 & Oconomowoc at Funk Road & $2,220,480$ & $1,071,360$ & $1,728,000$ \\
7 & Oconomowoc at North Lake & - & - & $2,039,040$ \\
8 & Oconomowoc at Westshore Drive & - & - & $3,049,920$ \\
9 & Oconomowoc at Cty Hwy K at Stonebank & - & $2,021,760$ & $3,257,280$ \\
\hline
\end{tabular}

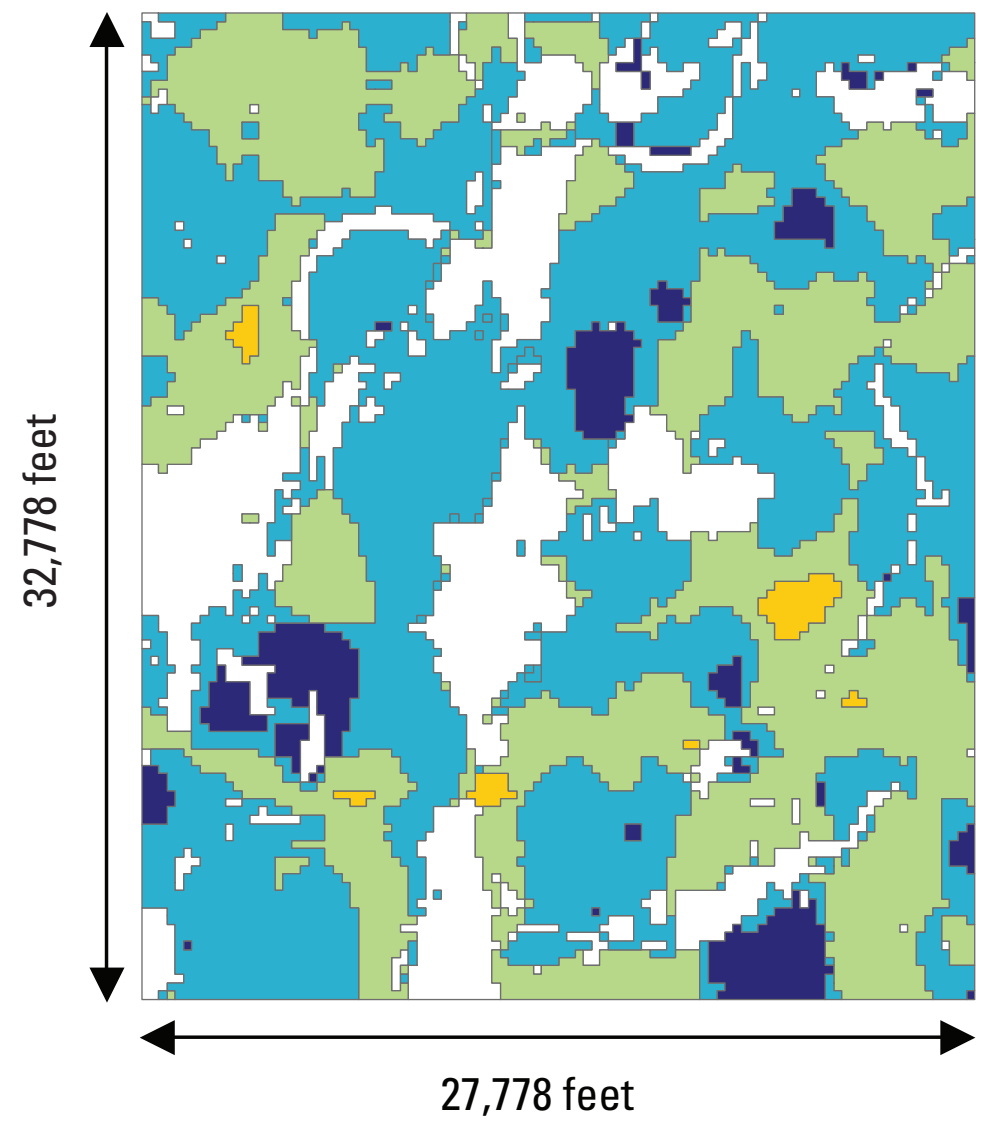

\section{EXPLANATION}

Groundwater recharge, in inches per year

19.5

11.7

7.8

3.9

$\square 0.0$

Figure 8. Recharge distribution in child model. 


\section{Hydraulic Conductivity and Storage Input to the Child Model}

In 2005, investigations were performed by the City of Delafield to plan for a new public-supply well to supplement the existing set of high-capacity wells in the area (fig. 9). An aquifer test conducted in late 2005 near Pine Lake in the City of Delafield ( Earth Tech, Inc., 2006), at the location marked "Test well" in fig. 9, provided new information on the hydraulic conductivity of the unconsolidated sediments in the vicinity of the Chenequa-area lakes, thereby allowing the original values from the background regional model to be updated. The USGS did not perform the aquifer test; details of the test, including 1) a detailed description of the test methods and procedures, 2) a map of the test site, 3) well construction, 4) site hydrogeologic characteristics, 5) time-discharge records of the pumped well, 6) water-level records, and 7) methods and computations of adjustments to measured drawdowns are included in Earth Tech, Inc. (2006). A hard copy of Earth Tech, Inc. (2006) is included as part of the physical aquifer-test archive, on file in the Wisconsin Water Science Center.
The purpose of the USGS analysis of the aquifer-test data was to evaluate aquifer properties to better characterize the child-model domain. As part of the USGS analysis, Earth Tech, Inc. (2006) aquifer-test data were incorporated in a special groundwater-flow model designed to reproduce the drawdown and recovery patterns observed during the aquifer test. The aquifer-test model treated the entire thickness of the glacial material near the test well as a single unconfined flow system. The model consisted of four layers (used exclusively to represent the glacial thickness) and a nonuniform lateral grid spacing centered on the pumping well. The row and column spacing increased by a factor of 1.2 outward from the pumping well, a resolution which allowed the three observation wells surrounding the pumping well to be precisely located horizontally as well as vertically. Boundary conditions were provisionally inserted to take account of surface-water features (Pine Lake and the Bark River); but, likely because of the distance to these features relative to the strength and duration of the aquifer-test stress, the model results were largely insensitive to presence or absence of boundary conditions. Earth Tech, Inc. reported that the pumping well was open approximately $200 \mathrm{ft}$ below land surface, corresponding

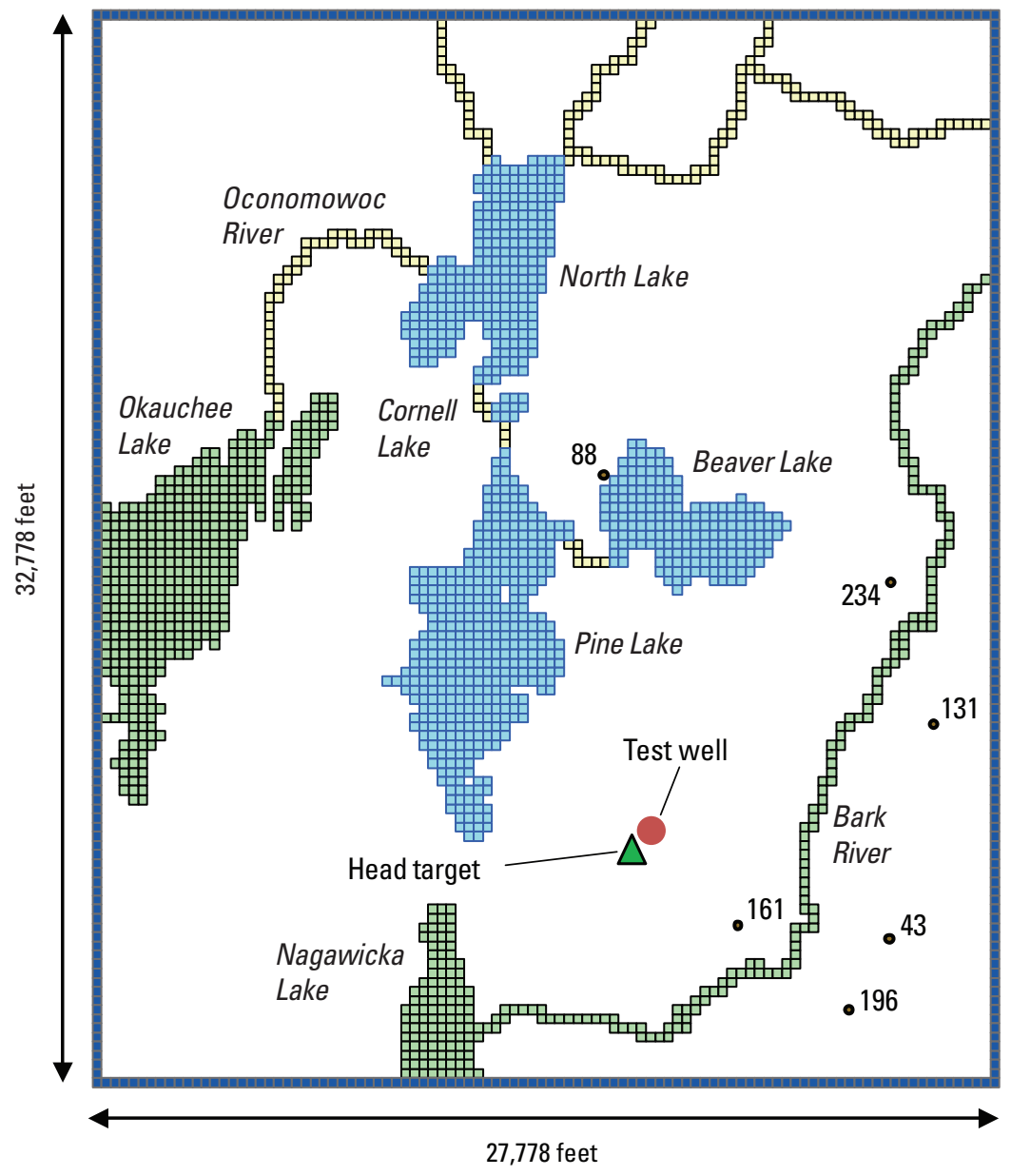

\author{
EXPLANATION \\ Model cell \\ 由 Constant head \\ $\boxplus$ River (RIV package) \\ $\boxplus$ Stream (SFR1 package) \\ 甲 Lake (LAK3 package) \\ 43. Pumping well, with pumping stress in gallons per minute
}

Figure 9. Location of pumping wells in child model. 
to model layer 4, and was pumped at a rate of $539 \mathrm{gal} / \mathrm{min}$ for 3 days. These pumping conditions were duplicated by the model, and a 3-day recovery phase of the test also was simulated. During the test, water levels were recorded at one observation well (OW-1) $150 \mathrm{ft}$ east of the pumping-test well and a second (OW-3) $300 \mathrm{ft}$ north of the pumping-test well. Both observation wells were open to the unconsolidated aquifer at the same elevation as the pumping-test well. A third observation well $150 \mathrm{ft}$ east of the pumping-test well was open at a shallower interval at the water table. This arrangement allowed the transient aquifer-test data to be used to calculate not only the horizontal but also the vertical hydraulic conductivity of the unconsolidated aquifer by fitting the shallow and deep water-level responses simulated by the model to the observed responses.

A close fit was achieved between the observed drawdown reported by Earth Tech, Inc. ${ }^{1}$ and the drawdown simulated by the aquifer-test model (fig. 10) when the horizontal hydraulic conductivity in the east/west direction was assigned a value of $55 \mathrm{ft} / \mathrm{d}$, the horizontal hydraulic conductivity in the north/ south direction was assigned a value of $110 \mathrm{ft} / \mathrm{d}$, and the vertical hydraulic conductivity was assigned a value of $1 \mathrm{ft} / \mathrm{d}$. The horizontal anisotropy of 2:1 between the east-west and north-south directions possibly represents a directional fabric of the outwash deposited in the bedrock valley, which crosses the child-model domain from its northeast corner in a south to southwest direction. Although the simulation of the deeper wells was good (figs. $10 B$ and $10 C$ ), the simulated response in the water-table observation well OW-2 (fig. 10A) duplicates the slope of the observed response but not the absolute trends. The likely reason for this discrepancy is that the groundwaterflow model releases storage immediately by the mechanism of pore drainage; however, in the actual test, this source of storage is slightly delayed at the beginning of the test, and the only actual storage release is due to the elastic response of the aquifer, producing a very steep initial drawdown curve. Nevertheless, the close fit to the slope of the drawdown suggests that the model is successfully simulating the combined effects of pore drainage, vertical resistance to flow, and horizontal transmissivity with respect to the shallow observation well. The specific yield implied by the slope of the drawdown curve for the shallow observation well shown in figure $10 \mathrm{~A}$ is 0.06 ,

\footnotetext{
${ }^{1}$ The Earth Tech, Inc. report (2006) contains an analysis of the pumping test based on analytical solutions for leaky aquifers applied to the two deep observation wells, OW-1 and OW-3. Assumed in the analysis is that the aquifer is overlain by a leaky confining unit. These analyses yield an average transmissivity equal to $13,847 \mathrm{ft}^{2} / \mathrm{d}$ and a storativity equal to $1 \times 10^{-4}$. For comparison to the values derived from the numerical modeling described above, if the aquifer thickness is assumed to be between $150 \mathrm{ft}$ and $200 \mathrm{ft}$ (depending on the thickness of the supposed confining unit), the isotropic hydraulic conductivity implied by the analytical solution is between 69 and $92 \mathrm{ft} / \mathrm{d}$. The reported storativity, corresponding to the response of a semiconfined aquifer, and implying a specific storage of approximately $5 \times 10^{-7}$ per $\mathrm{ft}$ for a 200 -ft-thick aquifer, is much lower than the specific yield derived from the numerical model analysis, which reflects the dewatering of pores at the water table and the assumption that the entire glacial system is unconfined rather than semiconfined.
}

a value needed for the transient simulations with the child model.

The horizontal anisotropy and associated hydraulic conductivity of the unconsolidated layers in the child model were specified by using the aquifer-test results for most of the childmodel domain (fig. 11). However, in the southeastern corner of the domain east of the Bark River (an area that is not informed by the aquifer test on the west side of the river), lower hydraulic conductivities were assigned. The lower values are needed to properly simulate the divide between the Bark River watershed and the neighboring Pewaukee Lake watershed (located in the parent regional model) and to ensure that the Bark River is, on balance, a gaining stream where it crosses the child model. Evidence from well-drillers' logs in the vicinity indicates that the glacial deposits, in fact, do become finer starting from the area of the Chenequa lakes, which is dominated by outwash deposits, and moving southeast toward Pewaukee Lake and the Fox River, an area characterized by mixed clayey till, loamy till, and coarse channel deposits (Douglas Cherkauer, University of Wisconsin-Milwaukee, oral commun., December 2009). The lower horizontal hydraulic conductivity in the southeast corner of the child-model grid is paired with a lower value for vertical hydraulic conductivity $-0.03 \mathrm{ft} / \mathrm{d}$ - as opposed to a vertical conductivity equal to $1 \mathrm{ft} / \mathrm{d}$ over the remainder of the domain.

The abrupt transition between the hydraulic conductivity assigned the two unconsolidated layers in the child model and the parent regional model produced instability in the coupled LGR solution. The instability disappeared when the regional values were extended three rows and columns (about $800 \mathrm{ft}$ ) into the child grid, as shown in figure 11.

The zonation of hydraulic conductivity values assigned the bedrock layers of the child model is identical to the values input to the background regional model except in the case of layer 11, representing the deep sandstone aquifer units, where the child-model values are averaged across the multiple deep sandstone layers in the background regional model. Accordingly, the Silurian dolomite is assigned a horizontal hydraulic conductivity of $4 \mathrm{ft} / \mathrm{d}$ and a vertical hydraulic conductivity of $1 \times 10^{-2} \mathrm{ft} / \mathrm{d}$; the Maquoketa Formation is assigned a horizontal hydraulic conductivity that ranges from 0.3 to $0.0003 \mathrm{ft} / \mathrm{d}$ and a vertical hydraulic conductivity value that ranges from $1 \times 10^{-3}$ to $5 \times 10^{-6} \mathrm{ft} / \mathrm{d}$; the Sinnipee Group is assigned a horizontal hydraulic conductivity that ranges from 0.3 to $0.04 \mathrm{ft} / \mathrm{d}$ and a vertical hydraulic conductivity that ranges from $1 \times 10^{-2}$ to $5 \times 10^{-4} \mathrm{ft} / \mathrm{d}$; and the deep sandstone aquifer system layer is assigned a horizontal hydraulic conductivity between 2.0 and $4.0 \mathrm{ft} / \mathrm{d}$ and a vertical hydraulic conductivity everywhere in the neighborhood of $6 \times 10^{-4} \mathrm{ft} / \mathrm{d}$. As in the background regional model, the specific storage assigned to the bedrock layers in the child model is $2.6 \times 10^{-7} 1 / \mathrm{ft}$. 


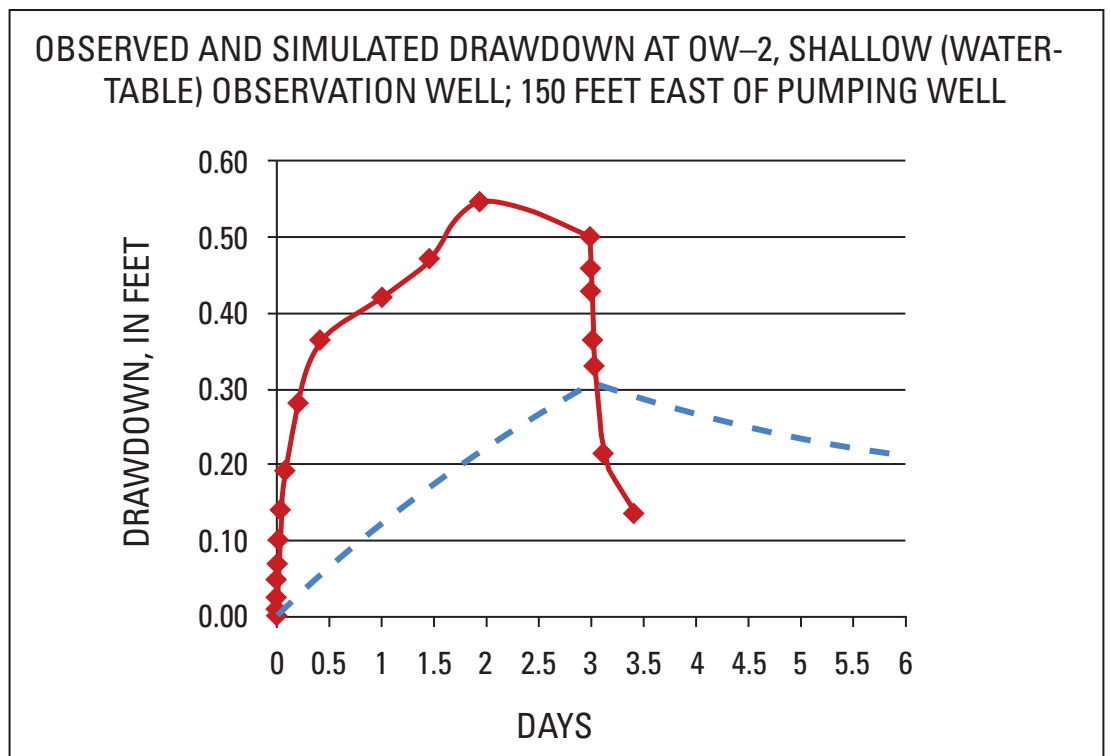

OBSERVED AND SIMULATED DRAWDOWN AT OW-1, 200-FOOT-DEEP OBSERVATION WELL; 150 FEET EAST OF PUMPING WELL

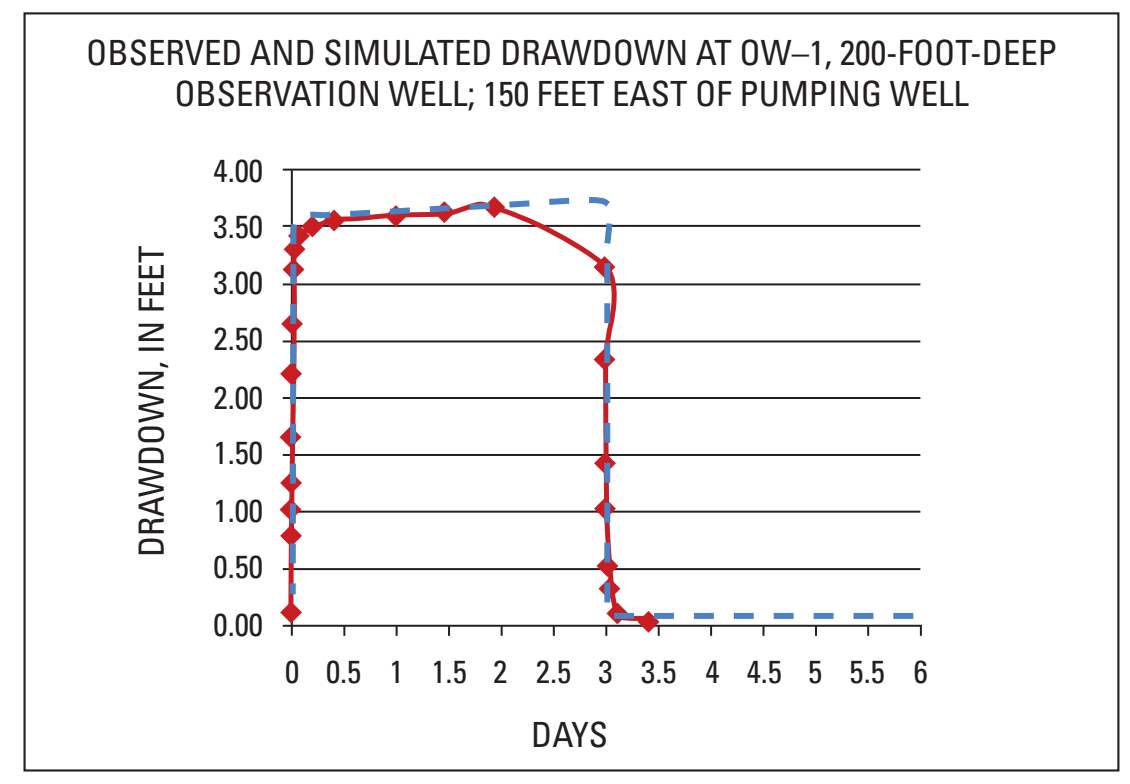

OBSERVED AND SIMULATED DRAWDOWN AT OW-3, 200-F00T-DEEP OBSERVATION WELL; 300 FEET NORTH OF PUMPING WELL

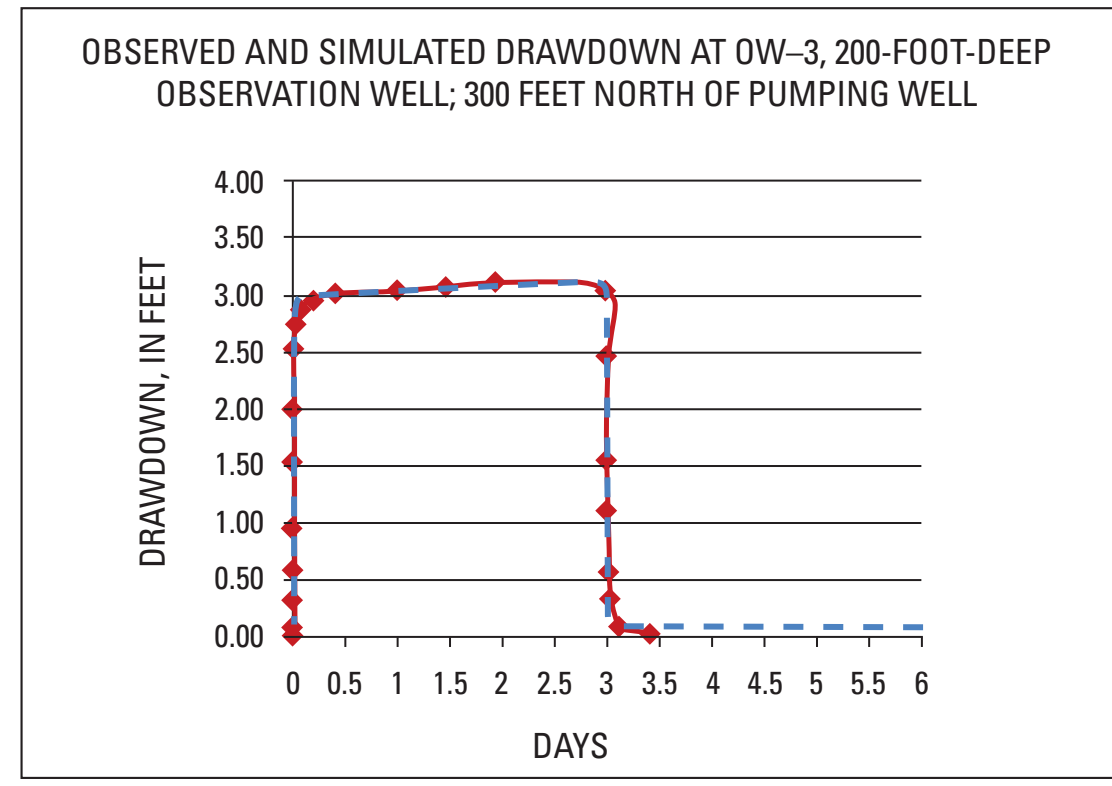

\section{EXPLANATION}

Observed drawdown

- - - Simulated drawdown
Figure 10. Aquifer-test analysis of drawdowns at three observation wells. (Note: The vertical drawdown scale for the shallow observation well is different from the scale for the two deep observation wells because much less drawdown was registered in the shallow observation well.) 


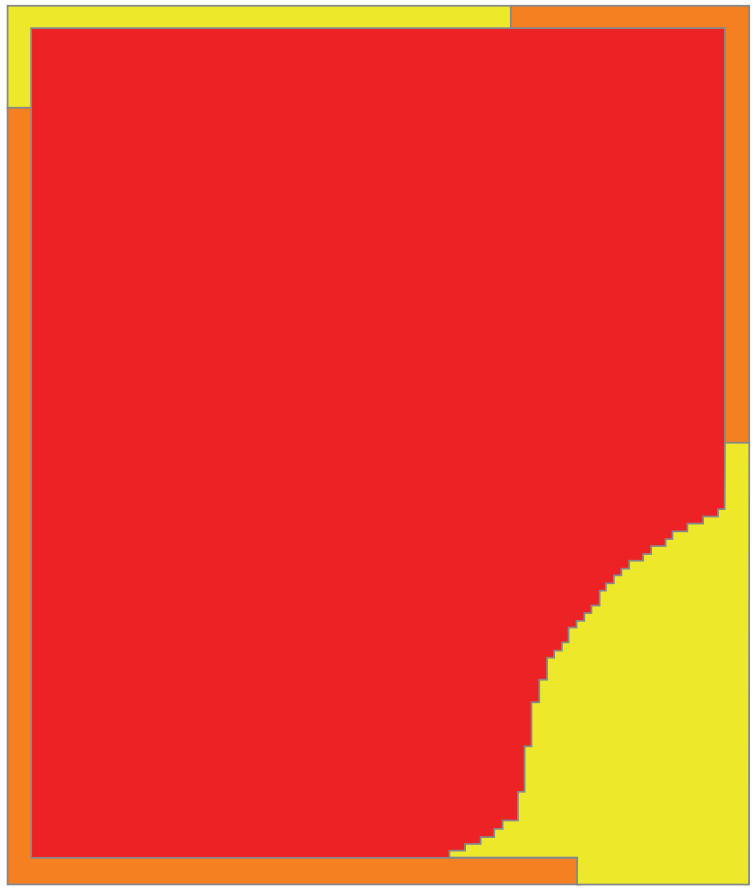

\section{EXPLANATION}

Layer 1

Horizontal hydraulic conductivity, in feet per day

55 east-west and 110 north-south
10
$\square$

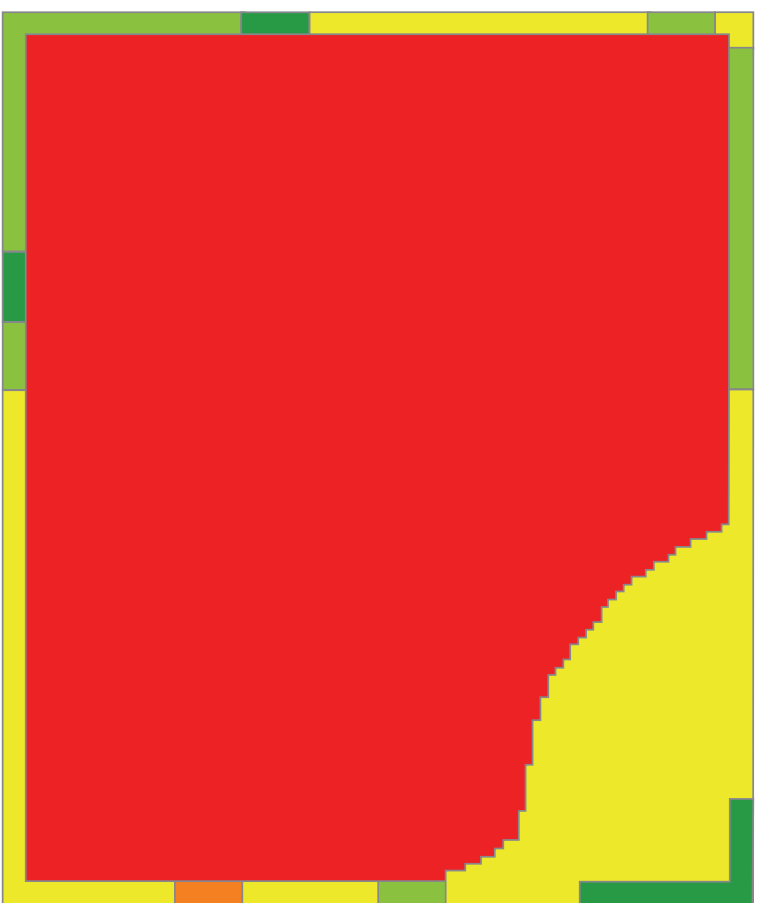

EXPLANATION

Layer 2

Horizontal hydraulic conductivity, in feet per day

55 east-west and 110 north-south

10

5

1

0.2

Figure 11. Distribution of horizontal hydraulic conductivity in child model, layers 1 and 2 . 


\section{Water Withdrawals from Wells in the Child Model}

Available records from the Wisconsin Department of Natural Resources and the Waukesha Public Service Commission provide estimates of average 2008 pumping from six high-capacity wells in the Chenequa area (fig. 9). The wells include one at the Chenequa Country Club on the shores of Beaver Lake, several Hartland public-supply wells located east and southeast of Beaver Lake, and a water-supply well for the city of Delafield. Each well withdraws water from the unconsolidated glacial aquifer; there are no records of active bedrock wells. The combined pumping from the six wells in the unconsolidated aquifer is $853 \mathrm{gal} / \mathrm{min}$. A seventh well, called Delafield2, began to pump in 2007. It is not included in the base version of the child model.

\section{Calibration of the Child Model}

Calibration of the child model consisted of trial-and-error adjustment of parameters to improve the agreement between observed and simulated values representative of average conditions for a limited number of targets. Five types of targets were used to calibrate the model:

- Stages for Beaver, Pine, and North Lakes, corresponding to elevations recorded on 1:24,000-scale U.S. Geological Survey quadrangle maps (Stonebank, 1959; and Merton 1959, revised 1971); the stage of Cornell Lake, a very small surface-water feature, was estimated as the average of Pine and North.

- A single water-level measurement near Pine Lake, collected at the outset of the Delafield pumping test from a water-table observation well ( Earth Tech, Inc., 2006). (See fig. 9 for location of head target.)

- An estimate of groundwater inflow to Beaver Lake, computed as the average of the calculated values for 1983-84 (1.36 $\left.\times 10^{6} \mathrm{ft}^{3} / \mathrm{d}\right)$ and for $1987\left(3.5 \times 10^{6} \mathrm{ft}^{3} / \mathrm{d}\right)$ reported by Carman (1988).

- Stream outflows from Beaver and Pine Lakes (see fig. 12 for outlet locations), equated with the average of the three field measurements reported in table 1.

- Gain in streamflow for stretches of the Oconomowoc River and Bark Rivers (see fig. 12 for measurement locations), based on streamflow measurements collected at times when base flow (that is, groundwater inflow) was likely responsible for most, if not all, of the streamflow. The calibration target for the Bark River was the average gain in streamflow between sites 3 and 4 in table 1 for the three measurement dates. The two calibration targets for the Oconomoc River were equal to the gain between sites 6 and 7 and between sites 8 and 9 for the September set of measurements only (owing to the availability of fewer than three measurements for some of the sites).

The calibration process was restricted to adjusting the location and configuration of hydraulic-conductivity zonation and values of the unconsolidated deposits (as described in the previous section) and the hydraulic conductivity of the beds of Beaver, Pine, Cornell, and North Lakes in an effort to improve fit. When a 1-ft lakebed thickness was assumed, the following lakebed hydraulic conductivities provided reasonably close agreement between the observed and simulated targets:

- Littoral value for Bark Lake, $2.5 \times 10^{-2} \mathrm{ft} / \mathrm{d}$.

- Littoral value for Pine and North Lake, $1.0 \times 10^{-2} \mathrm{ft} / \mathrm{d}$.

- Profundal value for Bark Lake, $2.5 \times 10^{-3} \mathrm{ft} / \mathrm{d}$.

- Profundal value for Pine and North Lake, $1.0 \times 10^{-3} \mathrm{ft} / \mathrm{d}$.

- Cornell Lake (very small), a single value of $1.0 \times 10^{-3}$ $\mathrm{ft} / \mathrm{d}$.

The agreement across targets is shown in table 2. The simulated lake stages are fairly close to the observed values, as are the base-flow gains in the Oconomowoc River. The simulated outflows from Beaver and Pine Lake and the base flow for Beaver Lake show larger discrepancies, but the overall rates of flow are comparable to the observed values given the temporal variability in the natural flows. The Bark River was not a primary calibration target, owing to its distance from the lakes of interest, and it is not well simulated. This poor representation of base flow in the Bark River is likely due to artifacts related to the model boundary conditions that poorly approximate the actual contributing areas to the flow system that are outside the child-model domain.

The calibrated child model corresponds to the base version of the child model. It incorporates the surface-water, recharge, aquifer hydraulic conductivity, lakebed hydraulic conductivity, and pumping inputs described in the previous report sections. Because the calibration of the child model was performed by trial and error, the calibration is likely not optimal in terms of reducing the target residuals (observed minus simulated values). In order to evaluate the quality of the calibration and its dependence on model inputs in greater detail, a sensitivity analysis was done in which the following sets of parameters of the child model were perturbed while all other inputs to the child and parent regional models were left unchanged:

1. The recharge rate applied to the water table.-The spatial distribution was left unchanged, but the rates were increased and decreased by 10 percent.

2. The horizontal and vertical hydraulic conductivities assigned model layers 1 and 2 corresponding to the unconsolidated material above bedrock.-The spatial zonation was left unchanged, but the values were increased and decreased by 30 percent. 


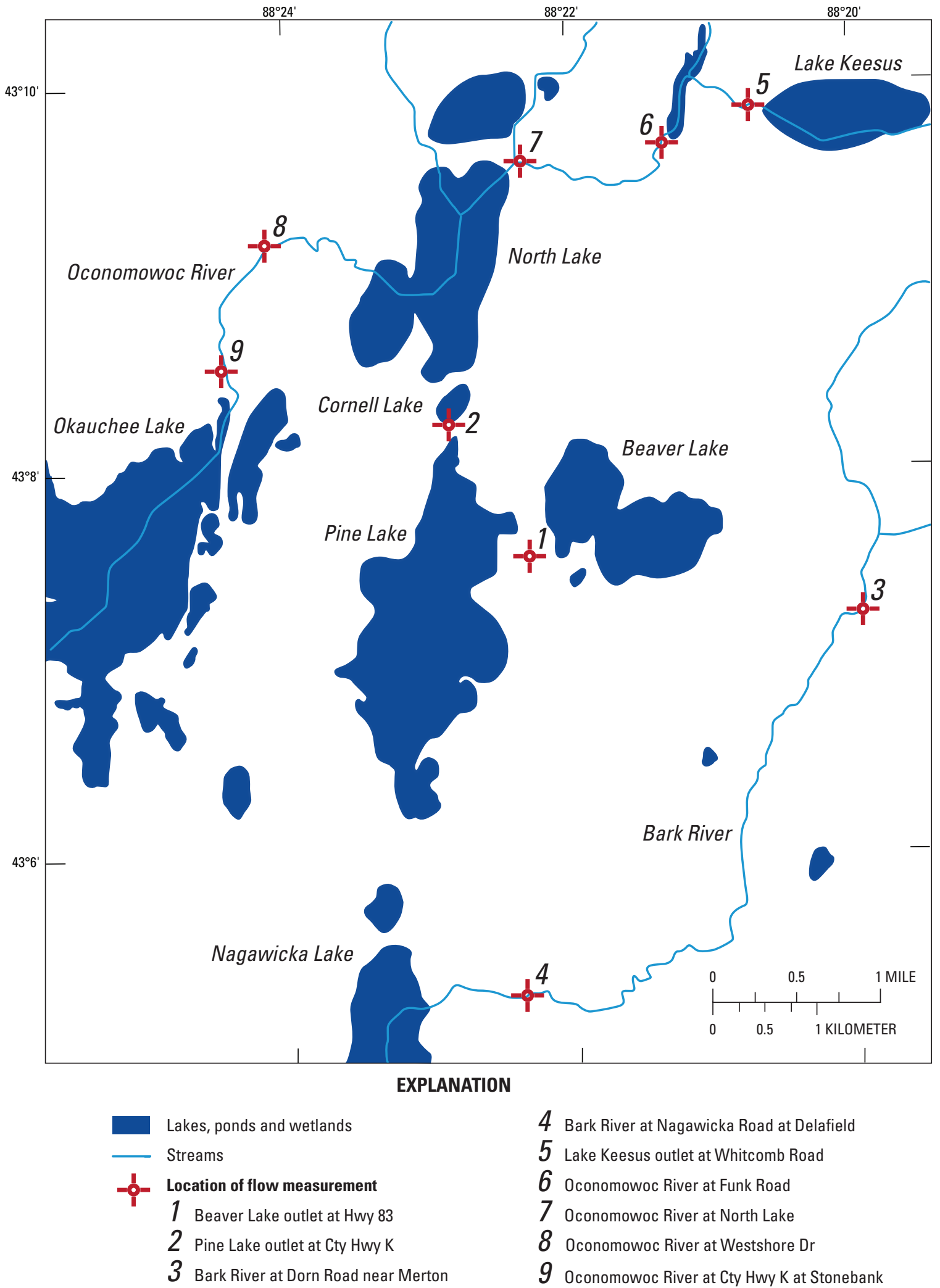

Figure 12. Locations of flow measurements. 
Table 2. Comparison of measured to simulated values for calibration targets for base-case simulation.

[Base case omits test well and incorporates average weather conditions (32 inches per year (in/yr) precipitation to lakes, 29 in/yr evaporation from lakes, and $8.5 \mathrm{in} / \mathrm{yr}$ average recharge to water table within local model area); $\mathrm{ft}^{3} / \mathrm{d}$, cubic feet per day]

\begin{tabular}{|c|c|c|c|}
\hline Stream or lake characteristic & Measured & Simulated & Difference \\
\hline \multicolumn{4}{|c|}{ Lake stage, feet above NGVD 29: } \\
\hline Beaver Lake & 909.00 & 909.62 & -0.62 \\
\hline Pine Lake & 900.00 & 900.27 & -0.27 \\
\hline Cornell Lake & 898.00 & 898.33 & -0.33 \\
\hline North Lake & 896.00 & 896.18 & -0.18 \\
\hline \multicolumn{4}{|c|}{ Lake outflow, $\mathrm{ft}^{3} / \mathrm{d}$ : } \\
\hline Beaver Lake & 64,512 & 107,082 & $-42,570$ \\
\hline Pine Lake & 86,458 & 59,122 & 27,336 \\
\hline \multicolumn{4}{|c|}{ Streamflow gain, $\mathrm{ft}^{3} / \mathrm{d}$ : } \\
\hline Bark River & 406,080 & 188,374 & 217,706 \\
\hline $\begin{array}{l}\text { Oconomowoc River, } \\
\text { Funk Road to North Lake }\end{array}$ & 311,040 & 284,754 & 26,286 \\
\hline $\begin{array}{l}\text { Oconomowoc River, } \\
\text { Westshore to Stonebank }\end{array}$ & 207,360 & 231,131 & $-23,771$ \\
\hline \multicolumn{4}{|c|}{ Groundwater: } \\
\hline $\begin{array}{l}\text { Groundwater level in test well, } \\
\text { feet above NGVD } 29\end{array}$ & 898.80 & 900.11 & .31 \\
\hline Base flow to Beaver Lake, $\mathrm{ft}^{3} / \mathrm{d}$ & 232,039 & 154,999 & 77,040 \\
\hline
\end{tabular}

3. The hydraulic conductivity assigned the lakebed sediments underneath Beaver, Pine, Cornell, and North Lakes.-The littoral and profundal zonation was left unchanged, but the values were multiplied by 5 and divided by 5 .

4. The net precipitation assigned Beaver, Pine, Cornell, and North Lakes.-The evaporation rate was changed so that the difference between precipitation and evaporation on the lakes was raised from the base value of $3 \mathrm{in} / \mathrm{yr}$ to $55 \mathrm{in} / \mathrm{yr}$ and reduced to $55 \mathrm{in} / \mathrm{yr}$.

The results for the eight sensitivity runs are presented in table 3 in terms of the change in residuals for each calibration target relative to the residuals in the base child simulation.

Two overall conclusions can be drawn. First, the base simulation yields lake levels that are somewhat too high, so reducing the recharge to the water table or reducing the net precipitation to the lakes has a favorable effect insofar as it results in lower lake levels. Second, none of the sensitivity changes produces consistent improvements across the remaining targets - the test-well water level, groundwater flows into Beaver Lake, surface-water outflows from Beaver and Pine Lakes, or baseflow rates to stretches of the Bark and Oconomowoc Riverssuggesting that the parameters in the base child simulation produce a reasonable overall fit with respect to these targets. The recharge and net precipitation rates in the base child model were maintained despite the overestimated lake levels because, as mentioned earlier, Village of Chenequa measurements from 2006 to 2008 indicated levels in Beaver and Pine Lakes 1 or $2 \mathrm{ft}$ higher than the values reported on topographic maps. Indeed, such variation is often expected in Wisconsin lakes (House, 1985). Given this evidence, it was judged counterproductive to lower recharge and net precipitation values linked to previous studies in order to reproduce target lake levels that are lower than recently recorded levels. 


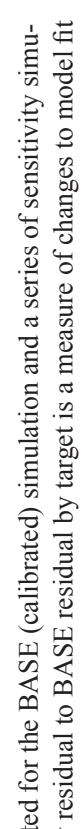

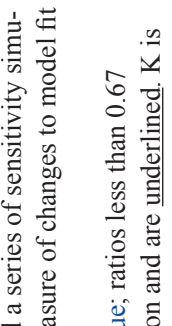

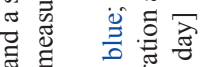

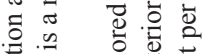

要

券

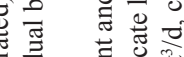

월

ह

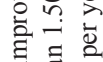

a 의

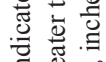

每.

空

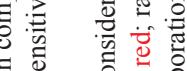

एँ

0응 흥

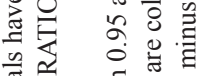

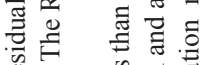

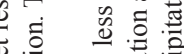

造

递密

t)

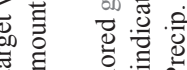

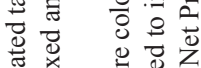

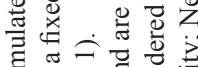

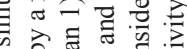

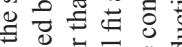

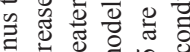

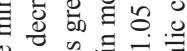

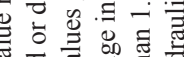

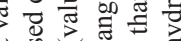

政

.气

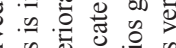

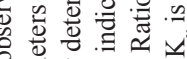

릴

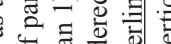

웅 $\Rightarrow$

p. द्वे

倠

元

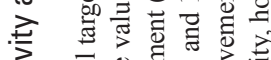

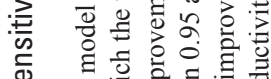

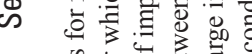

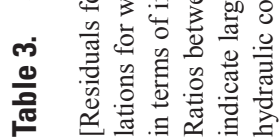

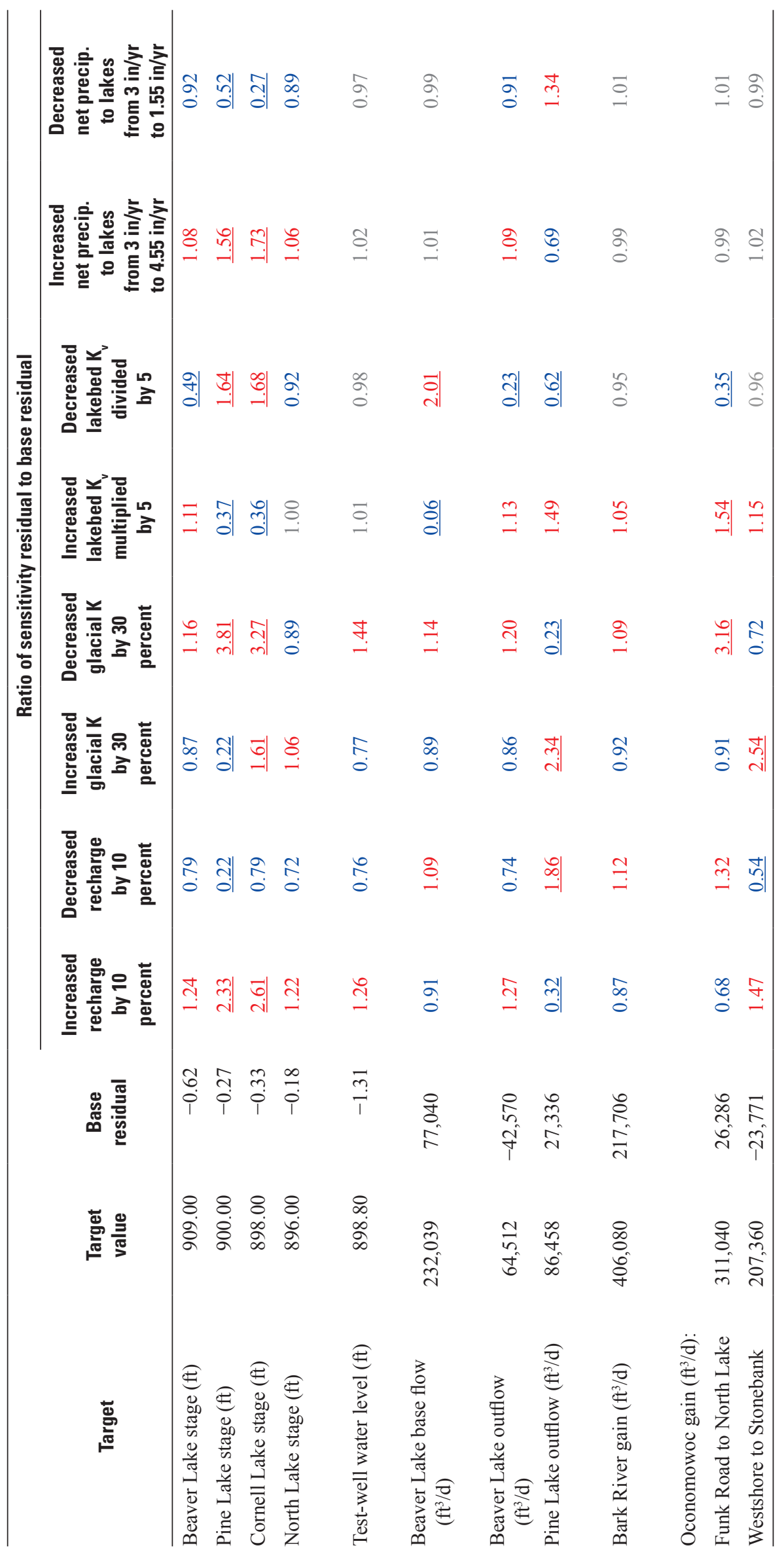




\section{Model Results}

The calibrated child model was used to simulate the hydrologic system in the Chenequa area under various weather and pumping conditions. The base-case condition is average weather (32 in/yr precipitation to lakes, 29 in/yr evaporation from lakes, and $8.5 \mathrm{in} / \mathrm{yr}$ average recharge to water table within child model area) and existing pumping from the shallow system within the child model - a total of $854 \mathrm{gal} / \mathrm{min}$ or $1.6 \times 10^{5} \mathrm{ft}^{3} / \mathrm{d}$ (fig. 9). The calibrated child model was used to simulate the water-table configuration for the study area (fig. 13). The model simulates the surface-water and groundwater fluxes under these conditions for each of the lakes (table 4); the terms of the water balance are precipitation, evaporation, groundwater inflow and outflow, and surfacewater inflow and outflow. This water balance is also depicted graphically for Beaver, Pine, and North Lakes (fig. 14). The comparison of the summed inflow and outflow terms of this balance for any lake is an indication of how well the model has succeeded in balancing inflows and outflows; this comparison is expressed as an error (as a percent of inflow). The balance in water fluxes also determines the stage of each lake under average weather conditions (table 5).

Dry weather conditions were simulated in child model by reducing the groundwater recharge and lake precipitation by one-third for a period of 5 years (lake evaporation was kept constant). This scenario was not intended to be a realistic simulation of a historical event (in which recharge and lake precipitation would not likely change in the exact same proportion and evaporation rates would probably not remain constant); rather, it was meant to be a heuristic treatment in the sense of showing possible effects of a severe, prolonged drought on the Chenequa-area lakes. For the same basecase pumping conditions ( $854 \mathrm{gal} / \mathrm{min}$ ), the surface-water and groundwater fluxes under dry weather conditions were

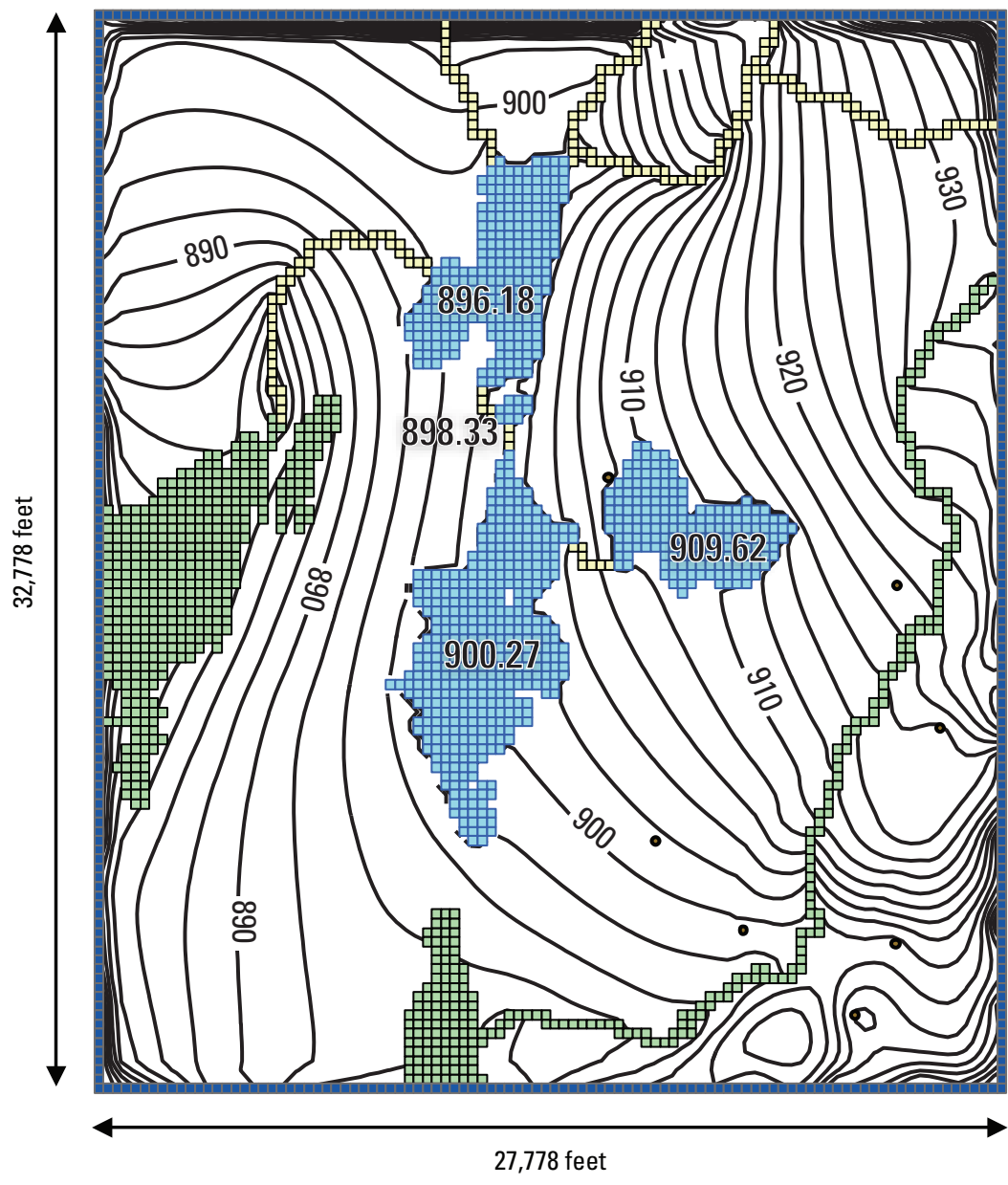

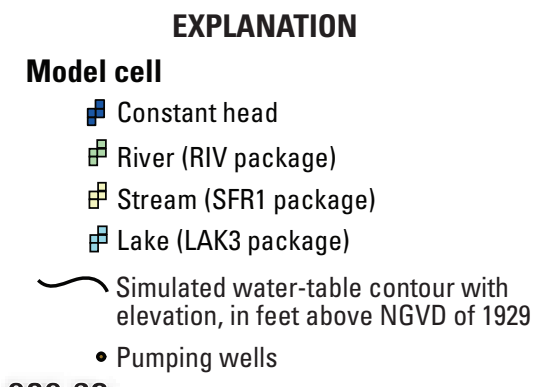

909.62 Simulated lake level

Figure 13. Child-model domain showing the simulated water-table elevation for the calibration run. (Steep contours along part of the child-model perimeter reflect the effect of the hydraulic-conductivity transition zone between the parent regional and child models used for numerical stability, as discussed in text.) 
Table 4. Lake budgets for base-case simulations.

[Base model omits test well and incorporates average weather conditions (32 inches per year (in/yr) precipitation to lakes, 29 in/yr evaporation from lakes, and $8.5 \mathrm{in} / \mathrm{yr}$ average recharge to water table within local model area); $\mathrm{ft}^{3} / \mathrm{d}$, cubic feet per day]

\begin{tabular}{|c|c|c|c|c|}
\hline \multirow{2}{*}{ Lake } & \multirow{2}{*}{$\begin{array}{l}\text { Precipitation } \\
\left(\mathrm{ft}^{3} / \mathrm{d}\right)\end{array}$} & \multirow{2}{*}{$\begin{array}{c}\text { Evaporation } \\
\qquad\left(\mathrm{ft}^{3} / \mathrm{d}\right)\end{array}$} & \multicolumn{2}{|c|}{ Groundwater } \\
\hline & & & $\begin{array}{l}\text { Inflow } \\
\left(\mathrm{ft}^{3} / \mathrm{d}\right)\end{array}$ & $\begin{array}{c}\text { Outflow } \\
\left.\text { (ft }{ }^{3} / d\right)\end{array}$ \\
\hline Beaver & $1.06 \times 10^{5}$ & $-9.60 \times 10^{4}$ & $1.55 \times 10^{5}$ & $-5.52 \times 10^{4}$ \\
\hline Pine & $2.18 \times 10^{5}$ & $-1.97 \times 10^{5}$ & $6.34 \times 10^{4}$ & $-1.37 \times 10^{5}$ \\
\hline Cornell & $5.64 \times 10^{3}$ & $-5.11 \times 10^{3}$ & $3.65 \times 10^{3}$ & $-3.48 \times 10^{1}$ \\
\hline North & $1.42 \times 10^{5}$ & $-1.29 \times 10^{5}$ & $1.23 \times 10^{5}$ & $-1.53 \times 10^{4}$ \\
\hline Lake & $\begin{array}{l}\text { Inflow } \\
\text { terms } \\
\left(\mathrm{ft}^{3} / \mathrm{d}\right)\end{array}$ & $\begin{array}{c}\text { Outflow } \\
\text { terms } \\
\left(\mathrm{ft}^{3} / \mathrm{d}\right)\end{array}$ & $\begin{array}{c}\text { Difference } \\
\qquad\left(\mathrm{ft}^{3} / \mathrm{d}\right.\end{array}$ & $\begin{array}{c}\text { Error } \\
\text { (percentage of } \\
\text { inflow) }\end{array}$ \\
\hline Beaver & $1.06 \times 10^{5}$ & $-1.06 \times 10^{5}$ & $1.06 \times 10^{0}$ & $-0.003 \%$ \\
\hline Pine & $1.06 \times 10^{5}$ & $-1.06 \times 10^{5}$ & $1.06 \times 10^{1}$ & $-0.018 \%$ \\
\hline Cornell & $5.64 \times 10^{4}$ & $-5.11 \times 10^{4}$ & $3.65 \times 10^{0}$ & $-0.006 \%$ \\
\hline North & $1.42 \times 10^{6}$ & $-1.29 \times 10^{6}$ & $1.23 \times 10^{2}$ & $-0.006 \%$ \\
\hline
\end{tabular}

simulated and compared to the average weather conditions (table 5). The comparison is expressed in terms of lake stage (Beaver, Pine, Cornell, and North Lakes) and lake outflow (Beaver and Pine Lakes).

Different pumping conditions were simulated in the child model by adding a test well in row 91, column 62, layer 2 . Two different rates were applied to this test well $-47 \mathrm{gal} / \mathrm{min}$ and $200 \mathrm{gal} / \mathrm{min}$. The magnitude of these rates can be scaled relative to the combined groundwater inflow to nearby Beaver and Pine Lakes: they represent 4 and 18 percent, respectively, of the lake groundwater inflow. For the two pumping scenarios, amounting to $901 \mathrm{gal} / \mathrm{min}(854+47 \mathrm{gal} / \mathrm{min})$ and 1,054 $\mathrm{gal} / \mathrm{min}(854+200 \mathrm{gal} / \mathrm{min})$ total discharge, the surface-water and groundwater fluxes were simulated and compared to the base-case pumping conditions amounting to $854 \mathrm{gal} / \mathrm{min}$ total discharge (table 6). The comparison is expressed in lake stage (Beaver, Pine, Cornell, and North Lakes) and lake outflow (Beaver and Pine Lakes). In addition, a simulation was done that compared surface-water and groundwater fluxes at base pumping conditions ( $854 \mathrm{gal} / \mathrm{min}$ ) under average weather conditions to a model pumping condition of $901 \mathrm{gal} / \mathrm{min}$ under dry weather conditions (table 7). This comparison is likewise expressed in terms of lake stage (Beaver, Pine, Cornell, and North Lakes) and lake outflow (Beaver and Pine Lakes).

Simulation of the source of water to wells lends insight into changes in the surface-water and groundwater fluxes resulting from different stresses due to pumping and weather. In table 8 , a comparison is made between base-case conditions (average weather and $854 \mathrm{gal} / \mathrm{min}$ pumping) and total pumping of 901 and 1,054 gal/min under average weather conditions, as well as between base-case conditions and $901 \mathrm{gal} / \mathrm{min}$ total pumping under dry weather conditions (table 8). The comparison in each case considers increased induced flow to groundwater from surface water, reduced base flow to surface water, increased net storage release, and decreased lateral net outflow. The comparison of these different simulations is expressed as the percentage of the total additional water that is coming from those four categories. The categories "increased induced flow to groundwater" and "reduced base flow to surface water" are both subdivided into the percentage of the total for that category coming from the Bark River and far-field lakes on the one hand and internal lakes (Beaver, Pine, Cornell, and North Lakes) on the other.

The groundwater inflow to the four lakes simulated under the range of weather and pumping conditions (average and dry weather and total pumping of 854,901 , or $1,054 \mathrm{gal} / \mathrm{min}$ ) is compiled in table 9, which provides a comparison of groundwater inflow for each lake under various conditions and between lakes for the same conditions.

One aspect of the model results that merits discussion is the role of storage release. Given that the simulation is transient, storage is a source and sink of groundwater. The smaller the contribution of storage relative to other sources and sinks of water, the closer the model is to a long-term steady-state condition and to stable water levels. By design, the base model simulation is very close to steady-state conditions throughout the 5-year observation period inserted subsequent to the 20 -year runup period. Storage release represents only 0.05 

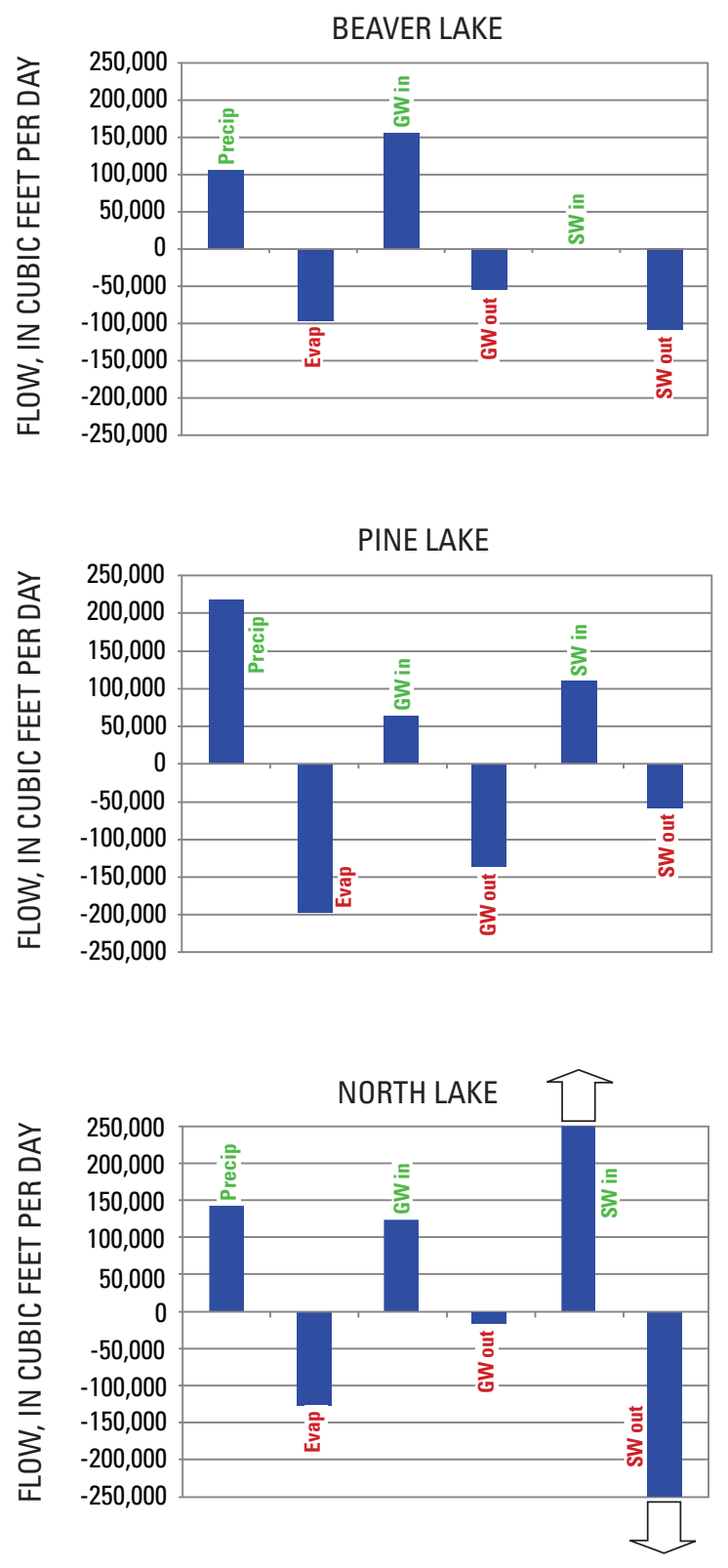

NORTH LAKE

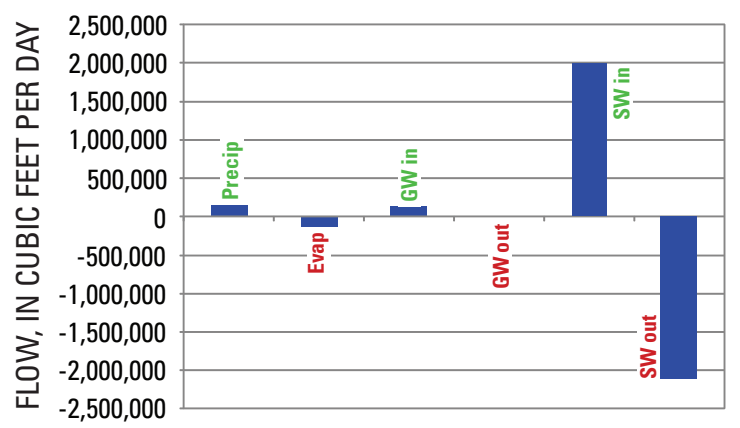

Figure 14. Simulated water budgets of Beaver, Pine, and North Lakes under base-case conditions. (North Lake is shown twice, at two scales.) percent of the total inflow to the child domain (dominated by recharge) after 6 months into the observation period and only 0.006 percent after 5 years, whereas storage uptake represents only 0.008 percent of the total outflow of groundwater (dominated by base flow to surface water) after 6 months into the observation period and only 0.0008 percent of total outflow after 5 years.

More careful analysis would be needed to quantify the approach to steady state in response to a simulated stress such as pumping or drought conditions. Both these types of stresses tend to lower the water table and release water from storage by draining pores at the water table. Starting from the same starting conditions after the 20 -year runup period as does the base model simulation, the two pumping scenarios show a decreasing contribution from storage over the 5-year observation period within the child domain. For the case where the simulated test well pumps $47 \mathrm{gal} / \mathrm{min}\left(9,126 \mathrm{ft}^{3} / \mathrm{d}\right)$, the storage inflow is 47 percent of the pumping stress 6 months into the observation period but only 2.5 percent of the stress after 5 years. For the higher simulated pumping rate equal to $200 \mathrm{gal} / \mathrm{min}\left(38,506 \mathrm{ft}^{3} / \mathrm{d}\right)$, storage release is also appreciable after 6 months ( 34 percent of the pumping stress) but again quite small after 5 years (1 percent of the pumping stress). The drought case shows a similar approach to steady-state conditions over the observation period. The difference in the recharge rate over the child domain between the base and drought simulations is $560,545 \mathrm{ft}^{3} / \mathrm{d}$. Storage release contributes 38 percent of this amount after 6 months of simulation but only 2.4 percent after 5 years. In general, the simulated groundwater-flow system shifts almost all the response to the simulated pumping and drought stresses away from storage release (proportional to declines in the water table) and replaces it, under stable water-table conditions, with water drawn from diverted base flow to surface water and from flow induced into the subsurface from surface water.

\section{Discussion}

The Chenequa-area lakes (Beaver, Pine, Cornell, and North) are explicitly represented within the child-model domain. Within this area, properties inherited from the background regional model have been changed to incorporate additional information and enhanced model capabilities. First, the child grid spacing, set at $278 \mathrm{ft}$ on a side, is much finer than that for the surrounding parent regional model, which inherited a spacing of 2,500 ft from the background regional model. The finer discretization permits a more accurate solution of water levels and flows in the vicinity of the lakes. Second, the LGR coupling allows stresses in the child model to propagate to the parent regional model (and vice versa), ensuring that the flows into and out of the child model are properly simulated. Third, the lakes and connecting waterways in the child model are represented by advanced modeling packages that allow for lake stages to be simulated instead of specified and for the 
Table 5. Simulated change to stage of Beaver, Pine, Cornell, and North Lakes and change to outflow from Beaver and Pine Lakes due to 5 years of dry weather conditions.

[gal/min, gallons per minute]

\begin{tabular}{|c|c|c|c|}
\hline \multirow{2}{*}{ Location } & \multicolumn{2}{|c|}{ Total pumping in child model } & \multirow{2}{*}{$\begin{array}{l}\text { Difference } \\
\text { in lake stage }\end{array}$} \\
\hline & $\begin{array}{l}\text { Average weather conditions }{ }^{1} \text {, } \\
\text { base run ( } 854 \mathrm{gal} / \mathrm{min})\end{array}$ & $\begin{array}{l}\text { Dry weather conditions }{ }^{2} \text {, } \\
\text { base run (854 gal/min) }\end{array}$ & \\
\hline \multicolumn{4}{|c|}{ Lake stage, feet above NGVD 29: } \\
\hline Beaver Lake & 909.62 & 908.97 & $-0.65 \mathrm{ft}$ \\
\hline Pine Lake & 900.27 & 896.62 & $-3.65 \mathrm{ft}$ \\
\hline Cornell Lake & 898.33 & 897.66 & $-0.67 \mathrm{ft}$ \\
\hline North Lake & 896.18 & 895.97 & $-0.21 \mathrm{ft}$ \\
\hline \multicolumn{4}{|c|}{ Lake outflow, cubic feet per day: } \\
\hline Beaver Lake & 107,081 & 21,367 & $-80 \%$ \\
\hline Pine Lake & 59,122 & $\approx 0$ & $-100 \%$ \\
\hline
\end{tabular}

${ }^{1}$ Average weather conditions correspond to 32 inches per year (in/yr) precipitation to lakes, $29 \mathrm{in} / \mathrm{yr}$ evaporation from lakes, and $8.5 \mathrm{in} / \mathrm{yr}$ average recharge to water table within local model area.

${ }^{2}$ Dry weather conditions last 5 years; recharge and lake precipitation reduced by one-third, lake evaporation kept constant.

Table 6. Simulated change to stage of Beaver, Pine, Cornell, and North Lakes and change to outflow from Beaver and Pine Lakes with test well pumped for 5 years at 47 gallons per minute and at 200 gallons per minute under average weather conditions.

[gal/min, gallons per minute; ft, feet; \%, percent]

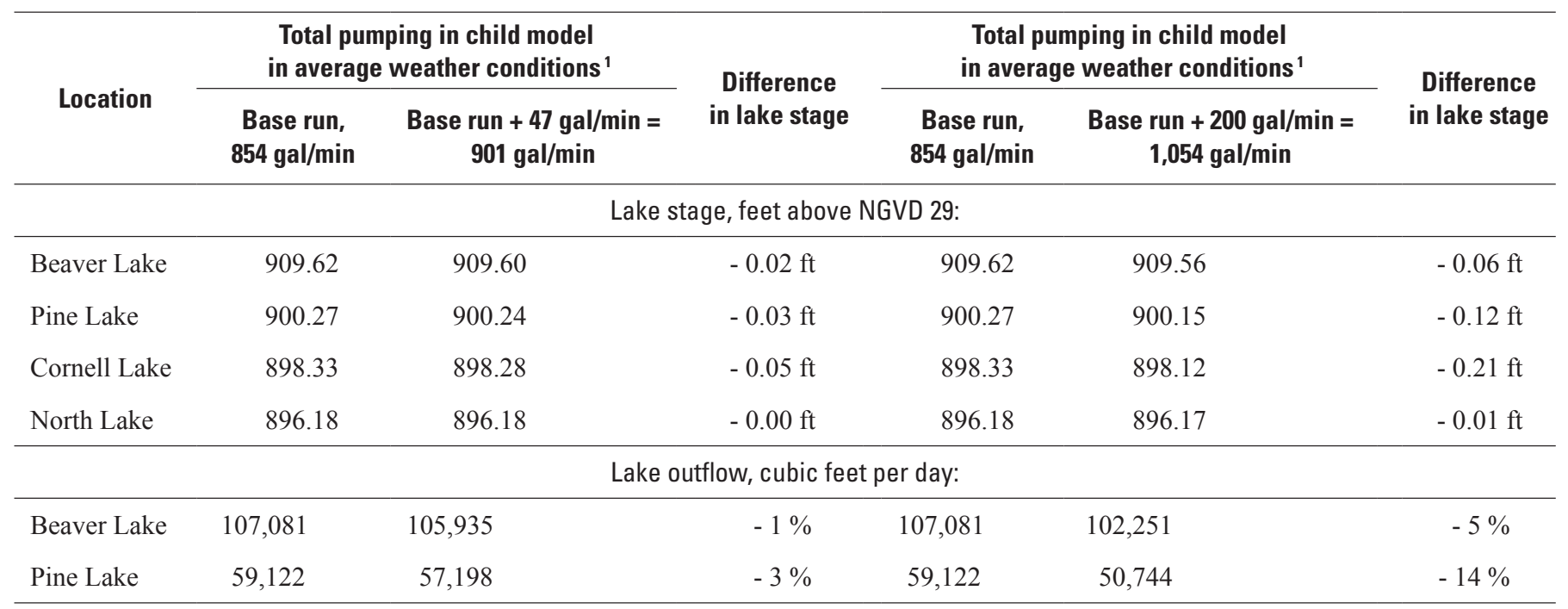

${ }^{1}$ Average weather conditions correspond to 32 inches per year (in/yr) precipitation to lakes, $29 \mathrm{in} / \mathrm{yr}$ evaporation from lakes, and $8.5 \mathrm{in} / \mathrm{yr}$ average recharge to water table within local model area. 
Table 7. Simulated change to stage of Beaver, Pine, Cornell, and North Lakes and change to outflow from Beaver and Pine Lakes with test well pumped for 5 years at 47 gallons per minute under dry weather conditions.

[gal/min, gallons per minute; $\mathrm{ft}$, feet]

\begin{tabular}{|c|c|c|c|}
\hline \multirow[b]{2}{*}{ Location } & \multicolumn{2}{|c|}{ Total pumping in child model } & \multirow[b]{2}{*}{$\begin{array}{l}\text { Difference } \\
\text { in lake stage }\end{array}$} \\
\hline & $\begin{array}{c}\text { Average weather conditions }^{1} \\
\text { Base run, } \\
854 \mathrm{gal} / \mathrm{min}^{\prime}\end{array}$ & $\begin{array}{c}\text { Dry weather conditions }{ }^{2} \\
\text { Base run }+47 \mathrm{gal} / \mathrm{min}^{2} \\
901 \mathrm{gal} / \mathrm{min}\end{array}$ & \\
\hline \multicolumn{4}{|c|}{ Lake stage, feet above NGVD 29: } \\
\hline Beaver Lake & 909.62 & 908.96 & $-0.66 \mathrm{ft}$ \\
\hline Pine Lake & 900.27 & 896.54 & $-3.73 \mathrm{ft}$ \\
\hline Cornell Lake & 898.33 & 897.64 & $-0.69 \mathrm{ft}$ \\
\hline North Lake & 896.18 & 895.97 & $-0.21 \mathrm{ft}$ \\
\hline \multicolumn{4}{|c|}{ Lake outflow, cubic feet per day: } \\
\hline Beaver Lake & 107,081 & 19,657 & $82 \%$ \\
\hline Pine Lake & 59,122 & $\approx 0$ & $100 \%$ \\
\hline
\end{tabular}

${ }^{1}$ Average weather conditions correspond to 32 inches per year (in/yr) precipitation to lakes, $29 \mathrm{in} / \mathrm{yr}$ evaporation from lakes, and $8.5 \mathrm{in} / \mathrm{yr}$ average recharge to water table within local model area.

${ }^{2}$ Dry weather conditions last 5 years; recharge and lake precipitation reduced by one-third, lake evaporation kept constant.

Table 8. Simulated sources to test well pumped for 5 years at 47 gallons per minute (for average and dry weather conditions) and at 200 gallons per minute (for average weather conditions).

[gal/min, gallons per minute; - , no percentages shown because the base run is the basis of comparison; values in bold type indicate totals]

\begin{tabular}{|c|c|c|c|c|c|}
\hline & \multicolumn{3}{|c|}{$\begin{array}{l}\text { Total pumping in child model in } \\
\text { average weather conditions }{ }^{1}\end{array}$} & \multicolumn{2}{|c|}{$\begin{array}{c}\text { Total pumping in child model in } \\
\text { dry weather conditions }{ }^{2}\end{array}$} \\
\hline & $\begin{array}{c}\text { Base run, } \\
854 \mathrm{gal} / \mathrm{min}\end{array}$ & $\begin{array}{c}\text { Base run + } \\
47 \mathrm{gal} / \mathrm{min} \\
=901 \mathrm{gal} / \mathrm{min}\end{array}$ & $\begin{array}{c}\text { Base run + } \\
200 \mathrm{gal} / \mathrm{min} \\
=1,054 \mathrm{gal} / \mathrm{min}\end{array}$ & $\begin{array}{l}\text { Base run, } 854 \\
\text { gal } / \mathrm{min}\end{array}$ & $\begin{array}{c}\text { Base run + } \\
47 \mathrm{gal} / \mathrm{min} \\
=901 \mathrm{gal} / \mathrm{min}\end{array}$ \\
\hline Source of additional water & & $\begin{array}{c}\text { Percentage of } \\
\text { total }\end{array}$ & $\begin{array}{l}\text { Percentage of } \\
\text { total }\end{array}$ & & $\begin{array}{c}\text { Percentage of } \\
\text { total }\end{array}$ \\
\hline Bark River and far-field lakes & - & 7.1 & 5.6 & - & 12.2 \\
\hline Internal lakes & - & 4.8 & 10.0 & - & 3.6 \\
\hline Reduced base flow to surface water & - & 74.3 & 78.6 & - & 75.6 \\
\hline Bark River and far-field lakes & - & 56.4 & 61.5 & - & 62.6 \\
\hline Decreased lateral net outflow & - & 13.2 & 5.2 & - & 7.1 \\
\hline TOTAL & & 100.0 & 100.0 & - & 100.0 \\
\hline
\end{tabular}

${ }^{1}$ Average weather conditions correspond to 32 inches per year (in/yr) precipitation to lakes, $29 \mathrm{in} / \mathrm{yr}$ evaporation from lakes, and $8.5 \mathrm{in} / \mathrm{yr}$ average recharge to water table within local model area.

${ }^{2}$ Dry weather conditions last 5 years; recharge and lake precipitation reduced by one-third, lake evaporation kept constant. 
Table 9. Simulated groundwater inflow to lakes under various pumping and weather conditions.

[gal/min, gallons per minute]

\begin{tabular}{|c|c|c|c|c|}
\hline Condition & Beaver Lake & Pine Lake & Cornell Lake & North Lake \\
\hline Base-case simulation & $1.55 \times 10^{5}$ & $6.34 \times 10^{5}$ & $3.65 \times 10^{3}$ & $1.23 \times 10^{5}$ \\
\hline Test well pumped $47 \mathrm{gal} / \mathrm{min}^{1}$ & $1.54 \times 10^{5}$ & $6.30 \times 10^{5}$ & $3.71 \times 10^{3}$ & $1.23 \times 10^{5}$ \\
\hline Test well pumped $200 \mathrm{gal} / \mathrm{min}^{1}$ & $1.53 \times 10^{5}$ & $6.13 \times 10^{5}$ & $3.92 \times 10^{3}$ & $1.23 \times 10^{5}$ \\
\hline Dry weather conditions ${ }^{2}$ & $1.28 \times 10^{5}$ & $8.82 \times 10^{4}$ & $1.59 \times 10^{3}$ & $9.16 \times 10^{4}$ \\
\hline $\begin{array}{l}\text { Dry weather conditions with test } \\
\text { well pumped } 47 \mathrm{gal} / \mathrm{min}^{1,2}\end{array}$ & $1.27 \times 10^{5}$ & $8.85 \times 10^{4}$ & $1.58 \times 10^{3}$ & $9.13 \times 10^{4}$ \\
\hline
\end{tabular}

${ }^{1}$ Test well pumps for 5 years.

${ }^{2}$ Dry weather conditions last 5 years; recharge and lake precipitation reduced by one-third, lake evaporation kept constant.

entire budget of each lake to be explicitly evaluated. Finally, the zonation of properties - notably, hydraulic conductivity and recharge - was updated in the child model by use of results from a recent aquifer test and new estimates of how recharge varies over space.

The simulated model results for base conditions show the relative importance of groundwater flow in the lake budgets (table 4 and fig. 14). Groundwater is the largest inflow component for Beaver Lake (equal to 59 percent of total inflow). For Pine and North Lakes, it is an important component (equal, respectively, to 16 and 5 percent of total inflow) but less than the contribution from precipitation and surface-water inflow.

Effects of changes to base conditions on the lake budgets range from negligible to substantial. The addition of a test well south of Chenequa at the reported 2008 pumping rate of $47 \mathrm{gal} / \mathrm{min}$ of the new Delafield well has little effect on lake stages or flows after 5 years of simulated pumping (table 6), by which time the low rate of storage release indicates that the groundwater-flow system in the child domain is very close to steady-state conditions. The stage and the surface-water outflow from Pine Lake are simulated to decrease by only $0.03 \mathrm{ft}$ and 3 percent, respectively, relative to base conditions. The chief explanations for these modest effects are the low pumping rate, the depth of the test well (which, like the new Delafield well, is assumed to pump from a horizon approximately $200 \mathrm{ft}$ below land surface), and the high transmissivity of the unconsolidated aquifer, which allows the well to draw water from upstream along the bedrock valley and to capture inflow from the Bark River. However, if the pumping rate of the test well is assumed to increase to $200 \mathrm{gal} / \mathrm{min}$, the decrease in Pine Lake outflow is appreciably larger: the simulated drop in outflow is 14 percent relative to base-flow conditions, although the drop in stage is only $0.12 \mathrm{ft}$.
Severe drought (represented by 5 years of precipitation and recharge rates reduced by one-third relative to base values) would cause correspondingly severe reductions in lake stage and flows (table 5). For example, the model indicates that, under the simulated dry condition, the level of Pine Lake would decline by $3.7 \mathrm{ft}$ and that surface-water outflow would cease because the lake level would be well below its outlet sill elevation. The simulated conditions are so severe that the small feature corresponding Cornell Lake, which is assumed to be underlain by relatively tight lakebed material, maintains a higher level than the upgradient Pine Lake (table 5). The addition of pumping at the $47-\mathrm{gal} / \mathrm{min}$ rate to dry weather conditions has little effect on the simulated outcome because the effect of the drought is so dominant (comparison of tables 5 and 7).

Pumping wells can affect lakes by reducing stage and flows; lakes can affect pumping wells (and the drawdown around them) by acting as a source of the water withdrawn. The lakes act as a source in two ways: lake water is transferred to the groundwater system (that is, increased induced flow) and groundwater that would otherwise discharge to lakes is diverted to the well (that is, reduced base flow). The model results (table 8) indicate that the lakes are a source of water for the test well: increased induced flow and reduced base flow from the Chenequa-area lakes together account for 23 percent of the water flowing toward the well at a pumping rate of $47 \mathrm{gal} / \mathrm{min}$. At a test rate of $200 \mathrm{gal} / \mathrm{min}$, the Chenequa lakes account for 27 percent of the well supply. By way of comparison, the contribution of other water bodies - the Bark River and outlying lakes - is about 65 percent of the test-well discharge for both the 47 - and 200 -gal $/ \mathrm{min}$ rates. 


\section{Model Limitations}

The child and parent models are simplifications of reality. Both discretize properties of the subsurface into a limited number of zones that only approximate heterogeneous natural conditions. The degree of connection between the shallow aquifer and surface-water features, both rivers and lakes, is not well known. Although stresses such as recharge and pumping change not only across space but also through time, they are represented in the child and parent models by time-constant values.

The application of advanced modeling techniques to the Chenequa study adds assumptions and limitations to the modeling process. The use of the LAK3 package to simulate stages and water budgets for Beaver, Pine, and North Lakes requires the specification of additional inputs, some of which are based on available data (for example, the bathymetry of the lake bottom) and some of which are only partly constrained by field observations (for example, the elevation of the outlets controlling surface-water flow draining the lakes and the assumption that overland flow to the lakes is a negligible part of their water budgets). More precise measurements of these elevations and flows could serve to update and improve the existing child model. Although changes were made to the unconsolidated hydraulic-conductivity fields within the childmodel domain on the basis of aquifer-test analysis, the parent regional model inherited all its parameter values from the background regional model, resulting in an abrupt shift in permeability at the child/parent boundary. The effect of this shift was mitigated by extending the regional hydraulic-conductivity values a short distance into the child-model grid (fig. 7).

The calibration process for the coupled child and parent regional model was done by trial and error. Although the quality of the calibration is acceptable, a more sophisticated automated approach to calibration applying a parameter-estimation code might improve the agreement between measured and simulated targets by further minor adjustment of parameter values. The calibration targets used to characterize flow through the lakes are associated with considerable uncertainty because available measurements show much variability, making it difficult to estimate the long-term average. Future measurements of these flows could be used to test the performance of the model, and, if necessary, provide justification for reevaluating inputs such as lakebed conductance and recharge and outputs such as target lake levels.

\section{Summary and Conclusions}

In cooperation with the Village of Chenequa, Wis., the Southeastern Wisconsin Regional Planning Commission and the Wisconsin Department of Natural Resources, the USGS characterized the hydrology of part of northwestern Waukesha County, with a particular focus on the interaction between the shallow aquifer and area lakes. A previous regional groundwater-flow model developed in conjunction with the Southeastern Wisconsin Regional Planning Commission was the framework for this effort and the starting point for development of an inset model for the project area embedded in a "parent" regional model. The complexity of the input to the inset model, or "child" model, is greater than that of the regional model and is commensurate with the extent of the existing data in the local area. The groundwater/surface-water system was simulated by using the combined three-dimensional, transient child and parent regional models. Given the focus of the study on shallow groundwater conditions, the computational burden could be reduced by modifying the layering inherited from the background regional model, reducing the original eight layers used to represent the deep sandstone aquifer system to a single layer in both the regional parent model and the embedded child model. The child model has greater grid resolution than the regional parent model: cell area is refined from 2,500 ft by $2,500 \mathrm{ft}$ to $278 \mathrm{ft}$ by $278 \mathrm{ft}$, a factor of 81 . The increased discretization permits a more accurate solution of water levels and flows in the vicinity of the Chenequa-area lakes. Beaver, Pine, and North Lakes were simulated within the MODFLOW groundwater-flow model by use of the LAK3 package, which allows for explicit calculation of lake budgets; selected stream reaches connecting the lakes were simulated with the SFR1 package which allows explicit calculation of stream stages. The Local Grid Refinement (LGR) package allowed hydrologic stresses in the child model to propagate to the parent regional model and vice versa. The zonation of properties - notably, hydraulic conductivity and rechargewere updated in the child model based on the basis of results from a recent aquifer test and the availability of new estimates of how recharge varies over space.

The simulated model results for base conditions show the relative importance of groundwater flow in the lake budgets: 59 percent of total inflow for Beaver Lake and 16 and 5 percent of total inflow, respectively, for Pine and North Lakes. Severe drought conditions are represented by 5 years of precipitation and recharge rates reduced by one-third relative to base value. Simulation of drought conditions shows severe reductions in lake stage and flows. For example, the model indicates that under the simulated dry weather condition, the level of Pine Lake will decline by $3.7 \mathrm{ft}$ and surface-water outflow will cease because the lake level is below its outlet sill elevation. The addition of a test well south of Chenequa at the reported 2008 pumping rate of $47.4 \mathrm{gal} / \mathrm{min}\left(9,126 \mathrm{ft}^{3} / \mathrm{d}\right.$, equivalent to 4 percent of the combined groundwater inflow to nearby Beaver and Pine Lakes in the absence of test-well discharge) has little effect on lake stages and fluxes, probably 
because of the modest pumping rate simulated in conjunction with the pumping depth of the test well (approximately $200 \mathrm{ft}$ below land surface) and the large transmissivity assigned the unconsolidated aquifer, which allows the well to draw water from upstream along the bedrock valley and to capture inflow from the Bark River. The model results indicate that although lake levels and fluxes are only modestly affected by simulated pumping, the lakes are important sources of water from the vantage point of the test well: increased induced flow and reduced base flow from the Chenequa-area lakes together account for 23 percent of the water flowing toward the well at a pumping rate of $47 \mathrm{gal} / \mathrm{min}$. At a simulated test rate of $200 \mathrm{gal} / \mathrm{min}$, they account for 27 percent of the well supply. By way of comparison, the contribution of other water bodies - the Bark River and outlying lakes - is about 65 percent of the test-well discharge for both the 47 - and $200-$ gal $/ \mathrm{min}$ rates.

The use of Local Grid Refinement in this study, allowing the boundary conditions of the child model to adjust to changing regional conditions, ensures that the flows into and out of the child model are properly simulated. This modeling approach is an important tool that allows simulated forecasting scenarios to account not only for changes to hydrologic stresses in the Chenequa area but also for changes in conditions in surrounding areas outside the child domain. In addition, the effect within the child model of regional trends, such as drawdown in the deep sandstone aquifer, can be simulated. This approach results in computational efficiency while representing both local and regional hydrogeologic characteristics and stresses.

\section{References Cited}

Brown, B.A., and Eaton, T.T., 2002, Bedrock geology of southeastern Wisconsin, chap. 5 of Groundwater resources of southeastern Wisconsin: Waukesha, Wis., Southeastern Wisconsin Regional Planning Commission Technical Report 37, p. 53-65.

Buxton, H.T., and Reilly, T.E., 1986, A technique for analysis of ground-water systems at regional and subregional scales applied on Long Island, New York, in Subitzky, Seymour, ed., Selected papers in the hydrologic sciences, 1986: U.S. Geological Survey Water-Supply Paper 2310, p. 129-142.

Carman, E.P., 1988, The water balance, hydrogeology, and chemical loading from ground water at Beaver Lake, Waukesha County, Wisconsin: University of WisconsinMilwaukee, M.S. thesis, 240 p.

Davison, R.M., and Lerner, D.N., 2000, Evaluating natural attenuation of groundwater pollution from a coal-carbonisation plant: Developing a local-scale model using MODFLOW, MODTMR and MT3D: Journal of the Chartered Institution of Water and Environmental Management, v. 14, no. 6, p. 419-426.

Earth Tech, Inc., 2006, Report on test well construction and aquifer performance testing, test well for well 2, Delafield, Wisconsin: Stevens Point, Wis., Report to Thomas J. Hafner, Director of Public Works, City of Delafield [variously paged].

Feinstein, D.T., Eaton, T.T., Hart, D.J., Krohelski, J.T., and Bradbury, K.R., 2005, Regional aquifer model for southeastern Wisconsin-Report 1, Data collection, conceptual model development, numerical model construction, and model calibration: Waukesha, Wis., Southeastern Wisconsin Regional Planning Commission, Technical Report 41 [pt. 1], $81 \mathrm{p}$.

Feinstein, D.T., Hart, D. J., Krohelski, J.T., Eaton, T.T., and Bradbury, K.R., 2005, Regional aquifer model for southeastern Wisconsin-Report 2, Model results and interpretation: Waukesha, Wis., Southeastern Wisconsin Regional Planning Commission, Technical Report 41 [pt. 2], 67 p.

Harbaugh, A.W., 2005, MODFLOW-2005, The U.S. Geological Survey modular ground-water model-The groundwater flow process: U.S. Geological Survey Techniques and Methods 6-A16 [variously paged].

Hart, D.J., Schoephoester, P.R., and Bradbury, K.R., 2008, Groundwater recharge in southeastern Wisconsin estimated by a GIS-based water-balance model: Prepared by the Wisconsin Geological and Natural History Survey for the Southeastern Wisconsin Regional Planning Commission, $23 \mathrm{p}$. 
House, L.B., 1985, Stage fluctuations of Wisconsin lakes: Wisconsin Geological and Natural History Survey Information Circular 49, 84 p.

Hunt, R.J., Steuer, J.J., Mansor, M.T.C., and Bullen, T.D., 2001, Delineating a recharge area for a spring using numerical modeling, Monte Carlo techniques, and geochemical investigation: Ground Water, v. 39, no. 5, p. 702-712.

Leake, S.A., and Claar, D.V., 1999, Procedure and computer programs for telescopic mesh refinement using MODFLOW: U.S. Geological Survey Open-File Report 99-238, 53 p. (Also available at http://az.water.usgs.gov/MODTMR/ tmr.html.)

Linsley, R.K., Jr., Kohler, M.A., and Paulhus, J.L.H., 1982, Hydrology for engineers ( $3 \mathrm{~d}$ ed.): New York, McGraw-Hill, $508 \mathrm{p}$.

McDonald, M.G., and Harbaugh, A.W., 1988, A modular three-dimensional finite-difference ground-water flow model: U.S. Geological Survey Techniques of WaterResources Investigations, book 6, chap. A1, 548 p.

Mehl, Steffen, 2003, Development and evaluation of local grid refinement methods for forward and inverse groundwater models: University of Colorado at Boulder, Ph.D. thesis, $161 \mathrm{p}$.

Mehl, Steffen, and Hill, M.C., 2002a, Evaluation of a local grid refinement method for steady-state block-centered finite-difference groundwater models: Computational Methods in Water Resources XIV, June 23-28, 2002, Delft, Netherlands, Developments in Water Science 47, Elsevier, Volume 1, p. 367-374.

Mehl, Steffen, and Hill, M.C., 2002b, Development and evaluation of a local grid refinement method for block-centered finite-difference groundwater models using shared nodes: Advances in Water Resources, v. 25, no. 5, p. 497-511.

Mehl, Steffen, and Hill, M.C., 2003, Locally refined blockcentered finite-difference groundwater models - Evaluation of parameter sensitivity and the consequences for inverse modeling, in Kovar, K. and Hrkal, Z., eds., Calibration and reliability in groundwater modelling-A few steps closer to reality: Wallingford, Oxfordshire [England], International Association of Hydrologic Sciences Publication 277, p. 227-232.
Mehl, Steffen, and Hill, M.C., 2004, Three-dimensional local grid refinement for block-centered finite-difference groundwater models using iteratively coupled shared nodesA new method of interpolation and analysis of errors: Advances in Water Resources, v. 27, no 9, p. 899-912.

Mehl, S.W., and Hill, M.C., 2005, MODFLOW-2005, the U.S. Geological Survey Modular Ground-water ModelDocumentation of shared node Local Grid Refinement (LGR) and the Boundary Flow and Head (BFH) package: U.S. Geological Survey Techniques and Methods book 6, chap. A12, 68 p.

Merritt, M.L., and Konikow, L.F., 2000, Documentation of a computer program to simulate lake-aquifer interaction using the MODFLOW ground-water flow model and the MOC3D solute-transport model: U.S. Geological Survey WaterResources Investigations Report 00-4167, 146 p.

Mudrey, M.G., Jr., Brown, B.A., and Greenberg, J.K., 1982, Bedrock geology map of Wisconsin: Wisconsin Geological and Natural History Survey, State Map 18, scale $1: 1,000,000$.

Prudic, D.E., Konikow, L.F., and Banta, E.R., 2004, A new streamflow-routing (SFR1) package to simulate streamaquifer interaction with MODFLOW-2000: U.S. Geological Survey Open-File Report 2004-1042, 95 p.

Rumbaugh, J.O., and Rumbaugh, D.B., 2007, Groundwater Vistas, version 5: Reinholds, Pa., Environmental Simulations, Inc., $375 \mathrm{p}$.

Ward, D.S., Buss, D.R., Mercer, J.W., and Hughes, S.S., 1987, Evaluation of a groundwater corrective action at the ChemDyne hazardous waste site using a telescopic mesh refinement modeling approach: Water Resources Research, v. 23, no. 4, p. 603-617.

Westenbroek, S.M., Kelson, V.A., Dripps, W.R., Hunt, R.J., and Bradbury, K.R., 2010, SWB-A modified Thornthwaite-Mather Soil-Water-Balance code for estimating groundwater recharge: U.S. Geological Survey Techniques and Methods book 6, chap. A31, $60 \mathrm{p}$.

Wisconsin Conservation Department, 1941 and 1955, Lake survey maps of Beaver Lake, Pine, Lake, North Lake: Accessed February 2007 at http://dnr.wi.gov/lakes/maps/ DNR/waukesha.htm. 
Publishing support provided by the U.S. Geological Survey

Science Publishing Network, Columbus Publishing Service Center

For more information concerning the research in this report, contact the Director, Wisconsin Water Science Center

U.S. Geological Survey

8505 Research Way

Middleton, Wisconsin 53562

http://wi.water.usgs.gov/ 
